\title{
Market access, supplier access, and Africa's manufactured exports: an analysis of the role of geography and institutions *
}

\author{
Ibrahim Elbadawi, Taye Mengistae, and Albert Zeufack \\ The World Bank
}

\begin{abstract}
In a large cross-country sample of manufacturing establishments drawn from 188 cities, average exports per establishments are smaller for African firms than for businesses in other regions. We show that this is mainly because, on the average, African firms face more adverse economic geography and operate in poorer institutional settings. Once we control for the quality of institutions and economic geography, what in effect is a negative African dummy disappears from the firm level exports equation we estimate. One part of the effect of geography operates through Africa's lower "foreign market access": African firms are located further away from wealthier or denser potential export markets. A second occurs through the region's lower "supplier access": African firms face steeper input prices, partly because of their physical distance from cheaper foreign suppliers, and partly because domestic substitutes for importable inputs are more expensive. Africa's poorer institutions reduce its manufactured exports directly, as well as indirectly, by lowering foreign market access and supplier access. Both geography and institutions influence average firm level exports significantly more through their effect on the number of exporters than through their impact on how much each exporter sells in foreign markets.
\end{abstract}

JEL Classification: F10, F12, O10, O11.

Key words: Economic geography; Institutions, International trade; Economic development; Manufacturing; Africa.

World Bank Policy Research Working Paper 3942, June 2006

The Policy Research Working Paper Series disseminates the findings of work in progress to encourage the exchange of ideas about development issues. An objective of the series is to get the findings out quickly, even if the presentations are less than fully polished. The papers carry the names of the authors and should be cited accordingly. The findings, interpretations, and conclusions expressed in this paper are entirely those of the authors. They do not necessarily represent the view of the World Bank, its Executive Directors, or the countries they represent. Policy Research Working Papers are available online at http://econ.worldbank.org.

* The authors would like to thank Pierre Richard Agenor and Jim Tybout for useful comments on an earlier version of the paper. 


\section{Introduction}

The lessons from recent development success stories suggest that they have either been facilitated by export-orientation (e.g. Korea and Taiwan) or have in fact been export-led (e.g. Chile, Mauritius, Tunisia and South East Asia). On the other hand, the marginalization of Sub-Saharan Africa (Africa, henceforth) in world trade, especially in the global market for manufactured exports, is regarded as one of the manifestations of the relative lack of economic growth in the region over the last thirty years. In this context, a recent World Bank report advocates export diversification as one of the main elements of the development strategies that countries in the sub continent need to follow for sustained growth and poverty reduction (World Bank, 2000). Whether or not Africa has a potential for diversifying its exports into manufacturing beyond traditional trade in primary commodities has consequently been a subject of debate among development policy experts.

The debate is based on three distinct views about the determinants of comparative advantage for manufactured exports. Two of these emphasize the role of "geography and endowment". The third stresses the role of "transaction costs". According to some, Africa cannot have comparative advantage in labor-intensive manufactures because of its higher endowment of natural resources relative to human capital. ${ }^{1}$ Others argue that there is huge unexploited potential for coastal African countries for the growth of exports of labor-intensive manufactures, provided that they concentrate economic activities along their coasts and turn their increasingly expanding urban centers into productive and efficient base for exports. ${ }^{2}$ In a similar vain, Collier $(1997,1998)$ argues that, for at least the majority of Africa, unusually high, and policy-induced, transaction costs are the main cause of its comparative disadvantage in manufactured exports. Available evidence, based on the analysis of aggregate data on manufactured exports, lends support to both the "geography" and "transaction cost" theses, while the "endowment" thesis appears to fail to account for the extent of Africa's marginalization in the market for manufactured exports. ${ }^{3}$

However, as it currently stands, macro-econometric analysis of the determinants of Africa's aggregate manufactured exports is fraught with conceptual and econometric problems. At the conceptual level, existing estimates of relationships between export performance and economy-wide macro indicators (of geography or of institutions) lack a trade-theoretic foundation. Such a foundation should explicitly model the mechanism through which the effects of geography or of institutions are transmitted to the exporting decisions of individual producers. At the level of estimation, macro-econometric modeling of the determination of Africa's manufactured exports is bedeviled by the endogeneity of institutions and some aspects of economic geography, for which there do not seem to be convincing remedies as yet. This is partly because there are not that many countries with long enough time series of observations on comparable indicators of

\footnotetext{
${ }^{1}$ See, especially, Wood 1997; Wood and Mayers 1998; and Wood and Berge 1997.

${ }^{2}$ For example,Bloom and Sachs (1998), Gallup and Sachs (1998), Sachs and Warner (1997).

${ }^{3}$ See for example, Elbadawi (1999) and Elbadawi and Soludo (1999).
} 
governance. We think that the bias that the problem would lead to in estimation can be drastically reduced by shifting the observation of the interaction between institutions and economic outcomes down to the level of the firm. The firm can more plausibly be assumed to take its institutional setting as given, while the assumption of exogeneity of institutions to aggregate economic outcomes might be difficult to sustain. Changing the unit of observation from the economy as a whole or the industry to the firm level can also facilitate the identification of certain elements of economic geography. At the same time, identification of the effects of geography and institutions should be easier in a crosscountry sample of firms than it could be in a one country sample. ${ }^{4}$

In this paper we offer a micro-econometric assessment of the role of economic geography and institutions in Africa's marginalization in global trade in manufactures in a way that seeks to address these methodological issues. ${ }^{5}$ The assessment is based on the estimation of a firm level structural exports equation and its reduced form, on observations on over 14000 manufacturing establishments sampled from 188 cities in 18 developing countries. Ten of the 18 countries and 61 of the 188 cities are African. The structural equation is derived from a new trade theory model of international inequality developed in Redding and Venables (2004). The equation has two transmission channels for the effect of economic geography on firm level exports, which Redding and Venables call "supplier access" and "foreign market access". Supplier access is an index of the cost at which firms acquire inputs while foreign market access is a proximity weighted measure of the size of export markets. Both variables depend on international and domestic distances as well as on other influences on domestic and international trade costs. The quality of institutions is one such influence. In addition, the domestic component of a firm's supplier access depends on the diversity and productivity of the broader domestic industry, that is, on what may be loosely called domestic "economic density". The model also allows for a direct effect of institutions on firm level exports, over and above their influence through supplier access and foreign market access.

Regression of firm level exports on country, industry, and time dummies shows that average exports per establishments are smaller for African firms than for businesses in other regions, which is what one would expect from a cross-country comparison of aggregate figures for manufactured exports. Our estimation of the structural exports equation shows that this is mainly because, on the average, African firms face more adverse economic geography and operate in a poorer institutional setting. A part of the effect of geography is transmitted through foreign market access: African firms are located too far from wealthier international markets. Another part is channeled through supplier access: African firms face steeper input prices. This is partly because of their longer physical distance from (cheaper) foreign suppliers. It is partly due to domestic substitutes for importable inputs being more expensive in Africa. Estimation of the

\footnotetext{
${ }^{4}$ This is because cross-country samples would have one more level of variation in geography and institutions.

${ }^{5}$ Ours is not the only micro-econometric analysis of the determinants of manufactured exports in Sub-Saharan Africa based on World Bank business survey data. Clarke (2005) analyzes similar data- from eight African countries to find that firm level exports are hampered by restrictive trade and customs regulation, but without going into the role of economic geography. See also Eifert, Gelb and Ramachandran (2005) for a firm level econometric investigation of the role of institutions and infrastructure in the international competitiveness of African manufacturers.
} 
structural equations also shows that the quality of institutions influences exports directly as well as indirectly, through its effects on supplier access or foreign market access.

Once we control for the quality of institutions and economic geography, what is in effect a negative African dummy disappears from both the structural and the reduced form equations that we estimate.

Estimation of the reduced form exporting equation provides further details in the form of information about the effects of individual aspects of economic geography and of institutional quality that the structural model knits into supplier access and foreign market access. The salient items here include, first, average firm level exports are lower for land locked locations, and for those that are further away from major international markets.

Secondly, average exports are larger for firms operating in larger national economies or in denser local economies. They are also larger where domestic transport infrastructure is better. Thirdly, average exports are larger where the rule of law is stronger and where there is less corruption. As should be expected, nearly each geographic or institutional variable influences exports significantly more through its effect on the number of exporters than through its impact on sales per exporter in foreign markets.

The existence of interaction between the effects of institutions and those of economic geography on manufactured exports is one reason why it probably would not be very useful to ask which of the two would be the more important drag on Africa's exports of manufactures. Another is the heterogeneity of the region and the rest of the developing world in both dimensions. This makes the answer dependent on which specific African countries are being compared, and against which external benchmarks. For example, a far greater share of the export gap of Uganda vis-à-vis Morocco is explained by Uganda's poorer institutions than that which can be attributed to its obvious trade cost disadvantages over Morocco. On the other hand, the fact that Uganda's average firm level exports are so much lower than Bangladesh's can be put down entirely to differences in economic geography.

In the next section we spell out our conceptual and empirical framework by summarizing the relevant features of the model in Redding and Venables (2004), and deriving from it the firm level structural exporting equation we estimate. As we do so,we will discuss how certain aspects of natural geography and institutional quality enter the structure, paving the way for their subsequent use in estimation as instruments for the two key explanatory variables of the model, namely, supplier access and foreign market access. This is followed by a discussion of our data in section three. Section four is an account of the main econometric issues arising from the model and the peculiarities of our data, and of how we have addressed them in arriving at our results. The findings are presented in section five. We conclude in section six.

\section{Theoretical and Empirical Framework}


We derive the firm level structural equation that we estimate from a conceptual framework set out in Redding and Venables (2004). ${ }^{6}$ This is a standard new trade theory model of the world economy consisting of $\mathrm{N}$ countries in each of which varieties of a differentiated manufacturing product are produced under increasing returns by a continuum of monopolistically competitive produces. Each variety is produced by a unique firm and can be used as a consumer good or as intermediate input, entering utility or production through the CES aggregator:

$U_{j}=\left[\sum_{i}^{R} n_{i} x_{i j}^{(\sigma-1) / \sigma}\right]^{\sigma /(\sigma-1)}, \quad \sigma>1$

where, $n_{i}$ is the number of varieties produced in country $i=1, \ldots, N ; x_{i j}$ is the quantity demanded in country $\mathrm{j}$ of the output of a firm in country $i$; and $\sigma$ is the elasticity of substitution between any pair of varieties. ${ }^{7}$

The dual of this quantity aggregator is the price index in country $\mathrm{j}$ :

$$
G_{j}=\left[\sum_{i=1}^{R} n_{i} p_{i j}^{1-\sigma}\right]^{1 / 1-\sigma}
$$

where, $p_{i j}$ is the price of a variety produced in country $i$ and exported to country $\mathrm{j}^{8}$

By applying Shephard's lemma to this index, the demand of country $j$ for each variety produced in country $i$ is obtained as

$x_{i j}=p_{i j}^{-\sigma} E_{j} G_{j}^{\sigma-1}$

where $E_{j}$ is aggregate expenditure in country $j$, and from which it can be seen that $\sigma$ is the own price elasticity of demand for each variety. The term $E_{j} G_{j}^{\sigma-1}$ determines the position of the market demand curve that producers of country $i$ face in country $j$, and is called the "market capacity" of country $j$ by Redding and Venables. It is the basis for their concept of "market access".

\footnotetext{
${ }^{6}$ See also Redding and Venables (2000) for an earlier version of the paper on which our generation of the empirical analogue of the concepts of supplier access and foreign market access draws.

${ }^{7}$ The following expression dispenses with firm or variety indices by using the fact that, in the model, all varieties produced in each country $i$ are demanded by country $j$ in the same quantity, so that aggregate quantity demanded in country $j$ of varieties produced in $i$ is obtained as the product of number of varieties or firms in $i$ and exports to $j$ per variety.

${ }^{8}$ Equation (2) is arrived from an expression in which weighted prices are summed over countries by using the fact that, in equilibrium, the price of an individual variety produced in country $i$ and exported to country $\mathrm{j}\left(=p_{i j}\right)$ is equal to the price of the same variety produced in country $j$ and exported to country $i\left(=p_{i j}\right)$.
} 
On the supply side, technology and factor markets are assumed to be such that, the profits of a firm in country $i$ are given by

$\pi_{i}=\sum_{j=1}^{N_{i}} p_{i j} x_{i j} / T_{i j}-G_{i}^{\alpha} w_{i}^{\beta} k_{i}^{\gamma} c_{i}\left[F+x_{i}\right]$

where $c_{i} F$ is a fixed cost component signifying increasing returns; $c_{i}$ is marginal input requirement ; technology is assumed to be a Cobb-Douglas transformation into output of an internationally immobile primary factor obtained at price $w$, a mobile primary factor of price $k$, and intermediate inputs of price $G_{i} ; \alpha, \beta$, and $\gamma$ are factor shares such that $\alpha+\beta+\gamma=1$; and $T_{i j} \geq 1$ is an iceberg transport cost factor, where $T_{i j}=1$ if trade is costless, so that $T_{i j}-1$ measures the proportion of output lost in shipping from $i$ to $j$.

Faced with the demand function (2), a profit maximizing firm sets an f.o.b. price, $p_{i}$, such that

$$
p_{i j}=p_{i} T_{i j}
$$

where

$$
p_{i}=\frac{\sigma}{\sigma-1} G_{i}^{\alpha} w_{i}^{\beta} v_{i}^{\gamma} c_{i}
$$

The first of these equations states that the selling price of a given variety varies between countries according to transport cost. The second implies that the aggregate f.o.b. price includes a uniform mark-up over marginal cost.

Rewriting the demand equation (3) in terms of f.o.b prices, $p_{i}$, and summing over $j \neq i$ gives

$$
X_{i} \equiv \sum_{j \neq i} p_{i} x_{i j}=p_{i}^{1-\sigma} \sum_{j \neq i} T_{i j}^{-\sigma} E_{j} G_{j}^{\sigma-1}
$$

where $X_{i}$ is total exports of a firm in country $i$. This is the basis of the firm level exporting equation that we estimate, and can be rewritten in terms of the twin geographic concepts of market access and supplier access. The market access, $M A_{i}$, of a firm in country $i$ is "an appropriately distance weighted sum of market capacities" of the domestic market of $i$ and all of its (potential) trading partners. It is given by

$$
M A_{i}=\sum_{j=1}^{N_{i}} T_{i j}^{1-\sigma} E_{j} G_{j}^{\sigma-1}
$$

The supplier access $S A_{i}$, of the same firm is "the analogous sum of supplier capacities", and is given by 
$S A_{i}=\sum_{j=1}^{N_{i}} n_{j} p_{j i}^{1-\sigma}=G_{i}^{1-\sigma}$

Substituting for $p_{i}$ in equation (7) from equation (5), and using (8) and (9) gives

$$
X_{i}=a_{i}(S A)_{i}^{\alpha}(F M A)_{i}
$$

where, $F M A_{i}=\sum_{j \neq i} T_{i j}^{-\sigma} E_{j} G_{j}^{\sigma-1}=(M A)_{i}-T_{i i}^{-\sigma} E_{i} G_{i}^{\sigma-1}$ measures foreign market access

(that is, the foreign component of $M A_{i}$ ), and $a_{i}=\left(\frac{\sigma w_{i}^{\beta} k_{i}^{\gamma} c_{i}}{1-\sigma}\right)^{1-\sigma}$.

In order to convert equation (10) into something estimable at any level, we need to find empirical counterparts of foreign market access, $F M A_{i}$, and suppliers access, $S A_{i}$, which we will discuss in the next section. In order to make the result of this conversion estimable at the level of the firm, we need to depart from the representative firm formulation of the model to introduce firm heterogeneity. We propose to do this by making $a_{i}$ firm specific. Our hypothesis that the quality of institutions is a determinant of a country's exports needs also be reconciled with the implications of equation (10). Institutions can influence exports through their effect on $F M A_{i}$ and $S A_{i}$. For example, certain aspects of institutions could influence trade costs and hence $T_{i j}$ in equations (8) and (9), but would otherwise have no effect on exports. Others could influence exports exclusively through their effect on the number of firms, $n_{i}$, and, in that sense, through $S A_{i}$. Still others could operate, not through foreign market access or through supplier access, but more directly through any of the determinants of $a_{i}$, that is, through their effects on factor prices $\left(w_{i}, k_{i}\right)$, or on productivity, $c_{i}$.

To signify these departures from the formulation in Redding and Venables (2004) we will index firms by $h$ and replace $a_{i}$ by $a_{i h}$, which has the same determinants as $a_{i}$, except that the determinants could now vary between firms. We will further assume that $a_{i h}$ can be expressed as some log linear combination of firm level controls, controls $s_{i c k}$, some aspects of institutional quality, institutions $_{i m}$, unobserved country effects, $\delta_{i}$ and a set of observables summed up in a zero mean random iid error term, $\varepsilon_{i k}$, so that $\log a_{i h}=\delta_{0}+\sum_{m} \delta_{1 m}$ institutions $_{i m}+\sum_{c} \delta_{2 c}$ controls $_{i c k}+\varepsilon_{i k}$, where $h$ indexes firms.

The structural firm level exporting equation we estimate is of the form $\log X_{i k}=\delta_{0}+\sum_{m} \delta_{1 m}$ institutions $_{i m}+\sum_{c} \delta_{1 c}$ controls $_{i c k}$ $+\alpha \log \hat{S} A_{i}+\delta \log F \hat{M} A_{i}+\varepsilon_{i k}$ 
where $F \hat{M} A$ and $\hat{S} A$ are estimates of $F M A$ and $S A$ respectively.

Because our data come from multiple locations or cities within each country we define supplier access both at the country and the city levels for estimation purposes. Foreign market access is also measured at the city rather than the national level.

\section{Data}

Our main data source is a series manufacturing business surveys carried out mostly by the World Bank in 10 African and 8 non-African countries. ${ }^{9}$ The surveys took place at various points over the years 1994 to 2003, and are all based on very similar instruments and sample designs. ${ }^{10}$ Typically, each country survey generated information on production and exporting statistics on each business for a period of 2 to 3 years. The number of data points analyzed is therefore larger than a mere count of the establishments covered might suggest. The total number of manufacturing establishments covered in all the 18 countries is 14097 . These were drawn from 10 industries (Table 1) and 188 cities and towns and are distributed by country as shown in Table 2 . Of 188 cities covered by the surveys, 61 are from African countries.

All countries in Africa on which establishment level survey data are available on exporting activities and key firm level controls are included in our dataset. And the only criterion use in the selection of the 8 non-African countries in the set was availability of comparable data on the same set of variables. Other studies of firm performance and international trade based wholly or partially on the dataset include, Bigsten et al. (1999), Dollar el al (2004), Mengistae and Pattillo (2004), Eifert et al. (2005), and Clarke (2005). ${ }^{11}$

Each country survey dataset included 2 to 3 years of observations on each establishment covering employment, sales, assets, ownership share, investment, and exporting activities. The key variables of interest to us are establishment level exports, the determination of which we would like to investigate here while controlling for key business characteristics, namely, business scale as measured by employment, business age, and whether or not there is foreign investment in the business. Exact definitions of these four variables are provided in Table 1 along with full-sample descriptive statistics.

One aspect of Africa's smaller share in global trade in manufactures is that the fraction of manufacturers that participate in export markets is smaller in the region. The other is that Africa's average export sales per exporter are smaller. These patterns can both be seen in Table 2. For example, the proportions of exporters in the Bangladesh and Moroccan samples are 34 percent and 40 percent respectively. The only country for which we have

\footnotetext{
${ }^{9}$ The exceptions are the 1997 Ghana survey and the 1996 Tanzania survey carried out by the Centre for the Study of African Economies of the University of Oxford.

${ }^{10}$ The surveys of the mid to late 1990s were implemented under the World Bank's Regional Enterprise Development Program for Africa. The more recent surveys were carried out as part of the Investment Climate Surveys of the Bank's Private Sector Development and Development Economics departments.

${ }^{11}$ This is a subset of a much longer list of papers investigating a wide range of issues but using part or all of the survey dataset used here.
} 
a similar rate of export market participation in Africa is Zimbabwe (in the mid 1990s). The maximum rate seen at a later date for any of the other countries covered by our data is 22 percent for Kenya. Average exports per exporter are also several times larger in Bangladesh or Morocco than in Kenya or in Zimbabwe.

Although the number of African countries covered by the data is rather small, we would like to argue that, between them, the 10 adequately capture the diversity of economies in the region in terms of the level of development and export orientation of the manufacturing sector. With over a fifth of their respective samples exporting, Kenya and Zimbabwe represent countries where the manufacturing sector is significantly geared towards export markets. Ethiopia, Mozambique, and Nigeria represent the other extreme, namely, the group of countries where local manufacturing caters entirely to the domestic market. Cameroon, Cote D'Ivoire, Ghana, Tanzania, and Uganda, represent the middle group where between a tenth and a fifth of manufacturers are exporters. Relating to other dimensions, the 10 include large countries as well as small ones. Some are also land locked while most are not. We also have at least one country each from the Western, Central, Eastern and Southern parts of the region.

The eight non-African countries also seem to capture enough of the diversity of the rest of the developing world in terms per capita incomes, the size of the national economy, and share in the global trade in manufactures. Low income countries are also represented in this second list as are lower and upper middle income ones. The list also includes the three largest developing economies, namely, Brazil, China and India, which, between them, account for close to one half of the population of the developing world. We also have at least one representative of East Asia, South Asia, Latin America and North Africa and the Middle East. And, while there could be understandable aversion to comparisons of economic performance between extremely large economies and small ones, it must be emphasized, first, that the aim here is to assess the role of geography and institutions in explaining differences in the exporting behavior of the average firm in each country conditional on a range of firm characteristics (including size, age and line of business). Secondly, it is important to note that our identification of the effects of economic geography comes as much from within country variation in the geographic characteristics of the 188 cities and towns from which the establishments are sampled, as from differences between the 18 countries to which the cities and towns belong. In particular, it is important, in this context, that we measure both supplier access and foreign market access at the city or town level.

We measure the quality of institutions in terms of two of the national level composite governance indicators of Kaufmann, Kraay and Mastruzi (2005), namely, the rule of law index and the index for control of corruption. The rule of law index is a weighted average of normalized indices of "the quality of contract enforcement, the police, the courts, and the likelihood crime and violence" collected independently from diverse sources through a variety of instruments of observation. The control of corruption index is a similar average of indices of "the exercise of public power for private gain, including both petty and grand corruption and state capture." Each index ranges in value from -2.5 to 2.5, higher values indicating better institutional quality along the specific dimension it is 
designed to measure. Data are available for each of the 18 countries for the years 1996, 1998, 2002, and 2004. We have imputed for the firm survey years of 1994 to 1997 the governance indices of 1996. Likewise, we have assumed that governance indicators for 1998 apply to 1999 and 2000, while those of 2002 apply for 2001 as well. We impute for 2003 the observations of 2004.

Our analysis involves three sets of indicators of economic geography. One of these consist of the three key regressors of the structural exporting equation that we would like to estimate, namely, national supplier access, local supplier access and foreign market access. The second consists of aspects of natural geography that influence market access and supplier access through their direct effect on trade costs. These include distance from national and international markets, and proximity and access to the sea. The third consists of the size and productivity of domestic industry which is assumed to influence exports through its effect on the domestic component of supplier access, by which we mean the price index of domestic inputs.

The exact list of variables in the second set are given in Table 1, and includes the following: a) a dummy for whether or not the country in which an establishment operates is land locked; b) the area of the country where the establishment is based; and c) a variable that we have termed "international distance, which we define as the log of the distance (in $\mathrm{km}$ ) from the nearest port of the city in which the establishment is based scaled up by the national average of the ratio of CIF prices to f.o.b.. prices of imports in 1995. ${ }^{12}$ We include in the third set country GDP's, local (or city level) GDP's, and the paved percentage of a country's road network. City GDP being unavailable in every case, we estimate these by assuming that a city has the same share in a country GDP as it has in the country's population.

Turning to the geographic variables of the structural exports equation, we estimate (national) supplier access and foreign market access by using the following formulae that Redding and Venables (2000) propose in an earlier version of their 2004 paper. The formulae used to estimate foreign market access and national supplier access are, respectively:

$$
F \hat{M} A_{i}=\sum_{j \neq i} Y_{j}^{\hat{\rho}_{2}} \cdot d i s t_{i j}^{\hat{\rho}_{3}} \operatorname{bord}_{i j}^{\hat{\rho}_{4}} \cdot \Lambda
$$

and

$$
\hat{S} A_{i}=\left(Y_{i}\right)^{\hat{\rho}_{1}} T_{i i}^{1-\sigma}+\sum_{j \neq i} Y_{j}^{\hat{\rho}_{2}} \cdot \operatorname{dist}_{i j}^{\hat{\rho}_{3}} \operatorname{bord}_{i j}^{\hat{\rho}_{4}} \cdot \Lambda
$$

where,

$$
\Lambda=\left[\exp \left(\text { isl }_{i}\right)\right]^{\hat{\rho}_{5}}\left[\exp \left(\text { isl }_{j}\right)\right]^{\hat{\rho}_{6}}\left[\exp \left(\text { llock }_{i}\right)\right]^{\hat{p}_{7}}\left[\exp \left(\text { llock }_{j}\right)\right]^{\hat{\rho}_{8}}\left[\exp \left(\text { open }_{i}\right)\right]^{\hat{\rho}_{9}}\left[\exp \left(\text { open }_{j}\right)\right]^{\hat{p}_{10}}(14
$$

\footnotetext{
12 The ratio of c.i.f prices to f.o.b. prices of imports is a direct measure of iceberg transport costs which bilateral physical distances can at best proxy. The ratio minus unity gives the iceberg transport of imports, which depends not only on physical distance from sources of imports but also on the efficiency of ports and the competitiveness of markets in shipping and air services. The importance of the latter is illustrated by the fact that the 1995 transport cost for Cote D'Ivoire imports were $25 \%$ of the total value of imports. This contrasts sharply with the corresponding figure of $7 \%$ of its immediate neighbor, Ghana, which also had more or less the same sources of imports as Cote D'Ivoire in 1995.
} 
where $\mathrm{Y}$ is GDP, dist is the bilateral distance between country $i$ and country $j$, bord is a dummy for whether the two countries share a border, isl is a dummy for being an island, llock is a dummy for whether the country is landlocked, and open measures the degree of openness.

We estimate foreign market access here at the city level rather than at the country level, by replacing the distance variable dist by the variable "international distance," What we refer to here as national supplier access is the same thing as the supplier access variable in the Redding and Venables model. In addition, we measure supplier access at the local or city level as well, by modifying equation (13) to a) replace own country GDP, $Y_{i i}$, by own local GDP as defined above, and b) replace bilateral distance by our "international distance"; and c) setting domestic distance, dist $i i$ to unity.

To obtain the three access variables listed in Table 1, we needed the list of trading partners of our countries of interest and estimates of the $\rho$-parameters of equations (12) and (13). Redding and Venables (2000) obtained the parameters from the estimation of a gravity equation on aggregate data on a cross-section of 101 countries. We too have used their estimates here. ${ }^{13}$ We identified trading partners of the countries of interest based on the COMTRADE Database. ${ }^{14}$ Country GDP figures were obtained from World Bank's World Development Indicators. Domestic distances were calculated using the formula $T_{i i}{ }^{1-\sigma}=\operatorname{dist}_{i i} \hat{\delta}_{1}$, where dist $_{i i}=0.33(\text { area } / \pi)^{1 / 2}$, and "area" refers to the area of the territory of the country in question. We used the Sachs-Warner measure of trade openness all cases. Our source for city distance and population variables is the Geographical Information Systems (GIS) database.

We show the contrast between African and non-African economies with respect to the three access variables in Figures 1 through 3. In each figure the access index is scaled to India's. Figure 1 shows that the average firm of any of the African countries in our list has far less foreign market access than its Indian counterpart. By contrast the average firm in everyone of the non-African group has a significantly higher foreign market access than its Indian counterpart. As a rule, the average firm in Africa also has a far smaller national supplier access than its counterpart in any of the non-African economies (Figure 2). This situation is somewhat mitigated if we account for the fact that industrial firms in Africa tend to be more concentrated spatially, which is what we do when use the

\footnotetext{
${ }^{13}$ We thank Steve Redding for kindly providing the estimates. The equation estimated in Redding and Venables (2000) is$$
\log x_{i j}=\rho_{0}+\rho_{1} \log Y_{i}+\rho_{2} \log Y_{j}+\rho_{3} \log d i s t_{i j}+\rho_{4} \log \operatorname{bord}_{i j}+\rho_{5} i s l_{i}+\rho_{6} i s l_{j}
$$$$
+\rho_{7} \text { llock }_{i}+\rho_{8} \text { llock }_{j}+\rho_{9} \text { open }_{i}+\rho_{10} \text { open }_{j}+u_{i j}
$$

where, $x_{i j}$ is aggregate exports from country $\mathrm{i}$ to partner $\mathrm{j} ; u$ is a stochastic disturbance term, and other variables as described above in equations (13) and (14).

${ }^{14}$ Because trade statistics were incomplete for Africa, we had to use the "mirrored" (reported by partners) data for African countries. We limited this exercise to the top ten trading partners of each country since these accounted for more than ninety percent of annual trade volumes in each case.
} 
local supplier access variable (Figure 3). However, here also the average African firm turns out to have a smaller local supplier access than the average non-African firm.

In section five we will estimate the effect of foreign market access and supplier access on firm level exports. As an important step to that end we provide a more formal description of the contrast between the exporting behavior of African and non-African manufacturers than that given in Table 2 by regressing the log of establishment level exports on country dummies in the second column of Table 3. The excluded countries in the definition of dummies from the list of those that appear in the table are Ethiopia, Morocco, Pakistan and Peru. Between them, these four seem to adequately capture the extent of diversity among the 18 countries covered by our data in terms of export performance, geography, and the quality of institutions. Of the fourteen countries that explicitly figure in the table, 9 are African. Of the remaining five, four have large, positive, and statistically significant dummy coefficients, suggesting that average establishment level exports- for exporters and non exporters included-is larger for each of these compared to the combined average of the four exclude countries. In contrast, seven of the 9 African dummy coefficients are either negative or not statistically different from zero. The only positive, large and statistically significant African dummies are those of Kenya and Zimbabwe.

\section{Some econometric issues}

Clearly we are dealing with a censored dependent variable here. This is not only in the sense that exports cannot be negative, but also in that a firm's not exporting is assumed to be a corner solution to choice based on the profitability of exports. ${ }^{15}$ This makes the OLS estimates of column 2 of Table 3, biased for true values of country dummy coefficients. To avoid this bias we estimate (by maximum likelihood) a tobit specification of the export equation in column 3 , but again with country dummies as the only regressors. However, the coefficient estimates of column 3 confirm more or less what we read from column 2 in terms of African manufacturers exporting less than their counterparts in the other developing countries represented in our data. The typical African manufacturer is far less likely to enter export markets than the typical manufacturer in China, India, Bangladesh or Morocco. The typical exporting African manufacturers also sells less in foreign markets.

What are the reasons for these patterns? According to equation (11), they should include that African manufacturers have smaller foreign market access or a smaller supplier access or both. As a first step towards testing this hypothesis we include the three access variables defined among the regressors of the firm level export equation estimated in Table 3. These are the foreign market access index, the national supplier access index and the local (or city) supplier access index. To the extent that any of these influences exports, all or part of the component of the overall effect could be transmitted as impact on the growth, turnover or foreign ownership of domestic businesses. While it is possible

\footnotetext{
${ }^{15}$ See, for example, Melitz (2003) for a new trade-theoretic threshold model of exporting decisions of this kind, where firms that have passed a profitability (of exports) threshold export on scales that increase monotonically with profitability. While the profitability (of exports) can thus in principle be inferred from the scale of exports for exporters, the dispersion of the (potential) profitability of exporting cannot be observed from their exporting status. What is being censored our is thus not the scale of exports but rather the profitability of exporting for non-exporters.
} 
that access variables operate exclusively through their effect on FDI and the size and age distribution of domestic firms, it is unlikely that all three variables are completely determined by supplier access and foreign market access. We will therefore include business size, business age, and whether or not the business involves equity participation by foreigners among the controls in our estimation of equation (11) in columns 1 and 4 of Table 3. In much of what follows, we will refer to business size, business age and foreign ownership collectively as "business characteristics" when there is no need to differentiate between the three variables. In addition, we include the control-ofcorruption index of Kaufmann et al. as an indicator of an aspect of governance that seems to influence exports both directly as a trade cost item, and possibly through its influence on foreign direct investment and domestic business turnovers. ${ }^{16}$

Because of the censoring of the dependent variable, the specification that we need focus on is that of column 4. Censoring makes the least squares estimates of the influence of access variables as reported in column 1 inevitably biased. ${ }^{17}$ We should also note that the three access variables enter the estimated equation as generated regressors in the sense of Pagan (1984). Standard estimates of the variance-covariance matrices of the OLS estimators and of the maximum likelihood tobit estimator would therefore lead to standard errors that are invalid as they ignore the sampling error involved at the stage of estimating the regressors. In order to deal with this problem we use bootstrap techniques to obtain consistent standard errors in the estimation of both column 1 and column 2 , using 50 full sample replications in each case.

Estimated coefficients of all three access variables in column 4 of Table 3 are each positive and statistically significant. However, it would be erroneous to draw any conclusion from this since the estimates could be biased due to the possible endogeneity, not only of foreign market access and supplier access, but also of the age, size or ownership distribution of firms. For example, the greater is the fraction of firms in an economy, or the greater the reliance of the typical exporter on foreign sales, the greater could be the scope for growth for the average firm. The employment variable that we use as an indicator of scale could thus be endogenous. Similarly it could be argued that participation in export markets exposes firms to greater competition than they would be facing if they operated exclusively in the domestic market. As a result, business turnover rates could be higher in more open economies, that is, in economies where a greater fraction of firms are exporters or rely more on foreign markets. But this means that the age variable in Table 3 could be endogenous as well, in as far as higher business turnover rates could make the average business younger. Then there is the possibility that firms operating in export markets are more likely to attract foreign investors, just as it is possible that multinationals are more likely to make green field investments as export

\footnotetext{
${ }^{16}$ In anticipation of a result we will report later in the paper, rule of law index also influences firm level exports, but almost entirely through its influence on access variables and the size, age and ownership distribution firms. We therefore have excluded it from the specification estimated in Table 3.

${ }^{17}$ They are therefore reported here mainly as baseline regression with the help of which we can get a feel of the magnitude of the bias. While the coefficients reported in column 1 of are not strictly comparable with corresponding coefficients in column 4, there is a strong indication of OLS bias in that the coefficient of foreign market access in column 1 is negative and statistically significant but positive and statistically significant in column 4
} 
platforms in countries of proven exporting record. This makes the foreign ownership dummy of Table 3 endogenous.

More significantly, there are at least three reasons why the variables of supplier access and foreign market access used in the table should be endogenous to exports. One is that all three are generated regressors, which means they can only measure the underlying theoretical construct with error. ${ }^{18}$ The second source of endogeneity is that a country's own GDP directly enters our estimate of its supplier access. Since exogenous shocks to aggregate exports as a rule translate to movements in aggregate incomes in the same direction, this should be a significant source of dependence of the supplier access variables on average firm level exports. The third source is the fact that the GDPs of the main trading partners of a country enters our estimate of its foreign market access. It is quite plausible that an exogenous shock to a country's exports influences the GDPs of many of its trading partners, at least in large economy cases. It is also possible to think of persistent and global shocks that could influence both the exports of a country and the incomes of its major trading partners. ${ }^{19}$

We address the problem of endogeneity of regressors in Table 4 through instrumental variable estimation. Sufficiently lagged, the variables used in the construction of access variables as described in section 3 should be natural instruments for supplier access and foreign market access. These include the following indicators of physical geography and economic density: country population lagged five years, local GDP for 1995, the index of international distance, country area, the dummy for being land locked, the percentage of a country's road network that was paved in 1990 . We also include, among the instruments, the Sachs-Warner index of openness to trade and the rule of law index of Kaufmann et al. (2005). We propose to use all eight as instruments for business size, business age and the foreign ownership dummy as well. The underlying argument is again that rule of law, a policy of openness to trade, or any other exogenous determinant of supplier access and foreign market access, should also affect the rate of foreign investment as well as the size and age distribution of firms thought its effect on business turnover and business growth.

As a rather informal vehicle for an assessment of the validity of these instruments we reestimate the log linear specification of export equation (given in column 1 of Table 3) by two stage least squares using the full instrument set. The result is shown in the first column of Table 4. As should be expected, a Hausman-Wu test based on the estimates and error variance of column 1 of Table 4, rejects the null that all the six regressors that we have instrumented in column 1 of Table 4 are exogenous. Though not reported here, a separate Hausman-Wu test rejects the null that IV estimation in which business size and

\footnotetext{
${ }^{18}$ Recognizing the endogeneity of access variables in this sense and using the appropriate estimation technique is one way of addressing the problem of the fact that the standard errors that we would otherwise estimate would be invalid as suggested in Gawande (1997). As already noted, we have addressed the problem of incorrect standard errors in Table 3 by other means. That, however, leaves unaddressed the problem of inconsistency of estimates due to the ednogenity of the regressors arising from their measurement with error.

${ }^{19}$ While a distinct possibility the endogenety the control of corruption index to exports seems to be far less compelling than that of the access variables, foreign ownership or the age -size distribution of firms. More importantly, as will be reported later, we cannot reject the null that control of corruption is exogenous based on a Hauseman-Wu test comparing a specification in which the index is instrumented with one in which it is assumed to be an exogenous regressor.
} 
business age are assumed to be exogenous (but access variables and foreign ownership are not) is consistent. On the other hand, the null that the control of corruption index is exogenous cannot be rejected based on the comparison of column 1 of Table 4 with a modification of the specification in which we include the control of corruption index among the edogeneous regressors.

Since we have potentially more instruments than endogenous regressors in Table 4, the question arises whether or not all of the instruments are valid. As can be seen from the reported p-value of the Sargan test, the orthogonality conditions of validity cannot be rejected. Indeed, one of the reasons that the control of corruption index is not excluded from the regressors is that the Sargan test rejects the conditions when the instrument set is expanded to include it. This suggests that this particular aspect of the quality of institutions influences firm level exports directly as well as through the endogenous regressors of Table 4. On the other hand, the rule of law aspect of the quality of institutions seems to influence exports only through its effect on supplier and market access or on business characteristics. The overidentifying restrictions are not rejected when we include rule of law in the instrument set and when we do not. The outcome of the test is similarly unaffected by adding or dropping each of the other instruments at the margin from the full instrument set. In particular adding or dropping the paved percentage of the road network set does not alter the outcome. The Sargan test does reject the restrictions when we include the control of corruption index among the endogenous regressors just as it does when we the treat the same index as an instrument.

The reason that we consider this assessment of the validity of our instruments to be informal is that the overidentification tests are being carried out on the assumption that there are no other sources of edogeneity of regressors in the model. This, of course, is not true since censoring of the dependent variable is in fact one such source. As in Table 3, we propose to address the problem of endogeniety due to censoring by estimating the model as a tobit in Table 4 as well, but this time taking into account the endogeneity of some of the regressors for reasons other than censoring. ${ }^{20}$ The null of exogeneity of the instrumented regressors that is rejected by the Hausman-Wu test in the context of the linear model of column 1 of the table is rejected in the tobit context in column 2 by the Smith-Bludell test (Smith and Blundell, 1986). ${ }^{21}$

Although the Sargan test of column 1 of Table 4 cannot be carried out in the context of a tobit model, we still would like to conclude from it that it is unlikely that the same set of instruments would fail a formal overidentification tests in a tobit setting. It seems highly

\footnotetext{
${ }^{20}$ That is to say, due to a combination of simultaneity and measurement error (arising from the fact that some of the regressors are estimated).

21 It should be noted that this test is not based on the tobit estimation method used in Table 4, but rather on a two-stage procedure in the first stage of which we estimate, by OLS, a reduced form specification of each of the endogenous regressors as a function of the exogenous regressors. The residuals of each of the first stage regressions are then plugged in among the regressors in the maximum likelihood estimation of what would otherwise be a standard structural tobit model in the second stage. The null of the Smith-Blundell test is that the coefficients of all the residual regressors of the second stage tobit estimation are all zero. We see in columns 2 through to 4 of Table 4 that the null is easily rejected both when we control for business characteristics and when we do not.
} 
unlikely that a regressor that is orthogonal to the error term of a linear specification should be correlated with error term of the analogous tobit specification.

We use the same justification for the following informal assessment of the potential for the problem of weak instruments in the sense of, for example, Staiger and Stock (1997), that is, the consequences of our instruments being too weakly correlated with the endogenous regressors. One such consequence is that the IV estimates themselves would be biased (Nelson and Starz, 1990). ${ }^{22}$ One formal definition, due to Stock and Yogo (2003), is therefore that an instrument set is weak if the ratio of the bias of the IV estimates to the bias of OLS estimates is likely to exceed some tolerable level, B. Stock and Yogo (2003) propose a test for weak instruments that is based on this definition and on the Cragg-Donald statistic (Cragg and Donald, 1993). ${ }^{23}$ The null of the test is that the instrument set is weak in the sense that the relative bias of the IV estimator asymptotically exceeds B. The alternative is that the instruments are not weak. The null is rejected if the test statistic exceeds critical values that vary with, $B$, the number of instruments, $\mathrm{K}$, and the number of endogenous regressors, $\mathrm{R}$.

We obtain a value of 20.67 (column 1) for the instrument set used in Table 4. Stock and Yogo (2003) provide critical values at the $5 \%$ level of significance and for various configurations of $B=0.1,0.2$. 0.3; $R=1,2,3$; and $K=1,2, \ldots, 30$. Since we have $R=6$, we do not have the exact critical value that our statistic should be compared with. However, we can take advantage of the fact that for given $\mathrm{B}$ and given $\mathrm{K}$, the critical value strictly decreases with $R$, to use the critical values they provide for the case of $R=3$ as the upper bound to the true critical value we would ideally use. For a choice of $B=0.1$, so that the bias of the IV estimator is 10 percent of the bias of the OLS estimator, the critical value at $\mathrm{K}=8$ and $\mathrm{R}=3$ is 9.01 . The true critical value corresponds to $\mathrm{R}=6$ and should be even lower than that. We can therefore be confident that this particular test would reject the null of weak instruments. It would do so even more easily if we chose $B$ to be higher, say at $\mathrm{B}=0.2$, in which case the critical value at $\mathrm{K}=8$ and $\mathrm{R}=3$ is 5.69 . This outcome is consistent with the less conclusive but still useful diagnostics provided by Shia's partial R-squares (Shea, 1997) and their conventional counterparts as reported in Table 5. Each of these measures is positive and statistically significant (in terms of F-values not reported here) for each of the endogenous regressors. The bottom line is that there is no evidence that the estimation results reported in Table 4 suffer from a potential weak instrument problem. The important caveat remains, of course, that we draw this conclusion based on a test and a diagnostic that cannot be implemented or computed in the setting of a non-linear model.

\footnotetext{
${ }^{22}$ A second consequence is that conventional standard errors of many IV estimators including 2SLS, and inferences based thereof, become unreliable.

${ }^{23}$ That is to say, that is, the minimum eigenvalue of the matrix analog of the F-statistic (of the joint significance of the instruments) from the first stage regression of two stage least squares. The Stock-Yogo test should not be confused with the Cragg-Donald test, which is a test of the null that the model is underidentified
} 
In columns 2 through to 4 we estimate alternative tobit specifications of the firm level export equation using Newey's minimum chi-square estimator, which is asymptotically efficient. $^{24}$

A comparison of the results with column 4 of Table 3, suggests that the estimates of the effects of all the main regressors as reported in Table 3 are seriously biased, which is what we should expect given the outcome of the Smith-Blundell tests reported at the bottom of Table 4. In particular, the effect of foreign market access on firm level exports would seem be understated several times over if we ignored the endogeneity of the regressors of the structural export equation. So would be our estimate of the local supplier access variable. On the other hand, endogeneity bias leads to overestimation of the effect of national supplier access. The size effects in firm level exports that we read in column 4 of Table 3, and the effects of the control of corruption index are also very much biased upwards while age effects and the effect of foreign ownership are both hugely understated. Indeed, there are no firm age effects in exports according to Table 3, while the common finding that younger firms tend to be more export oriented comes through in column 3 of Table 4.

\section{Findings}

In spite of the obvious contrast between the estimates of the two tables, the main storylines emerging from Table 3 are confirmed in Table 4. The most important of these is that average exports per firm are smaller for African manufactures than for their counterparts elsewhere mainly because of their smaller supplier access, smaller foreign market access and poorer institutional environment. This can be seen from a comparison of column 2 of Table 4 with column 3 of Table 3 . The latter has country, sector and year dummies as the only explanatory variables. We see from it that six of the nine African dummies have negative coefficient or are much smaller than those of Bangladesh, China, India, and Malaysia. The change in specification involved in moving to column 2 of Table 4 is only that we controls for, among others, foreign market access, supplier access, and the control of corruption index in estimating the country effects. This produces a rather dramatic change in coefficients of country dummies. It is now the Bangaldesh, China, India, and Malaysia dummies that have large, negative and statistically significant coefficients, while coefficients of six of the nine African dummies are all positive, large and statistically significant. We interpret this as indication that practically the whole of

the export performance gap between African manufacturers and their counterparts in Asia can be attributed to Africa's disadvantage in terms market access, supplier access, and the quality of institutions. This must be qualified by the fact that we are also controlling for business characteristics in column 2 of Table 4 . It could be that the negative Africa dummies of column 3 of Table 3 of Table 4, reflect the fact that firms in region are inherently older and smaller. However, it is clear from column 3 of Table 4, where we do

\footnotetext{
24 .As shown in Newey (1987) the estimator is asymptotically equivalent to the application of Amemiya's generalized least squares (AGLS) as set out in Amemiya (1978). The AGLS is a two-step procedure whereby, in this case, one first estimates the reduced form tobit and then uses generalized least squares to solve for the structural parameters. The resulting estimates of the structural parameters are more efficient than those generated by the two-step conditional maximum likelihood estimator of Smith and Blundell (1986), on which the exogeneity tests reported in the table are based.
} 
not control for business characteristics that controlling market access, supplier access, and the quality of institutions alone would remove the negative "Africa dummy" of Table 3. Dropping the foreign ownership dummy in column 3 leads to decreases in the coefficient of the national supplier access while increasing those of foreign market access and the control of corruption index relative to what we see in column 2. However, it doest not change much the sign configuration or relative magnitudes of the coefficients of the country dummies. Dropping firm age and firm size from the list of controls does not change results in those terms either, with the exception that the coefficient of the Bangladesh dummy now becomes positive and statistically significant. ${ }^{25}$

It is possible that part of the reason that average exports are lower for African manufacturers in our data is that they are less competitive in the production of more exportable goods for reasons we cannot observe, that is, due to factors unrelated to intermediate input prices or to trade costs. It could also be that exports are more sensitive to market access and supplier access precisely for lines of production in which African manufacturers are comparatively good at. ${ }^{26}$ However, neither of these is likely to be a significant driver of the results of reported in Table 4 . This is partly because we have included industry dummies (for sectors listed in Table 1) in all the specifications estimated in that table. In order to investigate how far the effects of market access and supplier access variables that we estimate in columns 2 through to 4 would survive the removal of inter-industry differences in the sensitivity of exports to trade costs and intermediate input prices, we have estimated the firm level export equation for a ubiquitous but relatively narrow industry group, namely, garments and textiles. The results are reported in columns, 5 to 7 of Table 4 . These columns basically mirror what is reported in columns 1, 2 and 4 for all industries, first, in terms of the outcome of exogeneity and instrument validity tests conducted in the context of a log-linear export equation, and then as regards the result of the Smith-Blundell exogeneity test. Secondly, they show more or less the same configuration of signs of coefficients of country dummies. Once again, there is no evidence that average exports are lower for African manufacturers than for their counterparts in Asia, once we control for differences in access variables and the quality of institutions (column 6). This is true even if we ignored the fact that the average African manufacturer is older but smaller, on account of which both the probability and scale of exporting should be lower for an African firm (column 7). Thirdly, all three access variables have positive and statistically significant coefficients in column 6 . At the same time, we should note that each coefficient of access variables in column 6 is significantly lower than its counterpart in column 2.

\footnotetext{
25 This suggests that firm level scale effects could be a substantial part of the reason for that country's relatively high average firm level exports.

26 In the latter case, the coefficients of access variable will reflect industry effects, which is important given that not all industries are found on a significant scale in all countries.
} 
When we argue that, between them, foreign market access, supplier access and institutions explain Africa's manufacturing export performance, we are attributing ultimate explanatory power to the eight variables of economic geography and institutions we have used as instruments in Table 4 . The exogeneity and instrument validity tests we discussed suggest that aspects of the institutional environment that control corruption influence export performance directly as well as through market and supplier access, and possibly through their effects on FDI and the size and age distribution of domestic firms. They also show that those relating to rule of law seem to be operating only indirectly, that is, through access variables, the size and age distribution of firms, or through FDI. On the other hand, the tests suggest that economic geography influences exports only indirectly through its effect on foreign market access, on supplier access and, to a lesser extent, on business characteristics. ${ }^{27}$

We now turn to an assessment of the relative weight of individual elements of economic geography and institutions in export determination. In order to do this we estimate, in column 1 of Table 6 , the reduced forms of the specifications of Table 4 by maximum likelihood for all industries. Corresponding estimates for garments and textiles producers only are given in column 2 of the same table. The fact that we now no longer include generated regressors means that we do not have to worry any more about a potential source of bias in conventional estimation of standard errors. However, our right hand side variables are all measured at the city or country level in Table 6 while the dependent variable is observed at the firm level. This means that the errors of the estimated model will almost inevitably be correlated within cities or within countries, which in turn would lead to downward bias in conventional estimates of standard errors (Moulton, 1986, 1990). As a way of avoiding this bias, while maintaining as much comparability as possible with Table 4, we have estimated standard errors by bootstrapping techniques in Table 6 as well.

A convenient classification of the economic geography variables in Table 6 is into those relating to trade costs and those relating to economic density. The trade-cost related geographic variables are international distance, country area and the dummy for being land locked. The economic density variables are country population, local GDP and percent of paved roads. Then we have the three institutions-cum-policy variables, namely, rule of law, control of corruption, and openness to trade. Among the trade-cost geographic variables, international distance and being land locked have statistically significant coefficients with the expected sign both in column 1 and column 2 . The coefficient of country area is also negative in both cases as expected, but statistically significant only in the regression for garments and textiles. All three variables of economic density are positive and statistically significant in both the regression for all industries and the regression for garments and textiles only. Both indicators of institution quality have positive and statistically significant coefficients in both regressions. The

\footnotetext{
27 The reason we attach the greater weight to market access and supplier access as transmission mechanisms of the effect of economic geography is that, as should be expected, the partial correlation between the economic geography instruments and market access and supplier access is stronger than that between economic geography variables and firm size, firm age of the foreign ownership dummy. This can be seen from Table 5.
} 
coefficients of openness to trade are also positive and large, but not statistically significant in either equation.

The economic geography variables have the sign and magnitude of effects we should expect from our estimates of structural parameters in Table 4. So do institution variables. The main results include, first, that average firm level exports are lower for land locked locations and for those that are further away from major international markets. Secondly, average firm exports are in larger cities and where the national economy is larger. They are also larger where domestic transport infrastructure is better. ${ }^{28}$ Thirdly, average exports are larger where the rule of law is stronger and where there is less corruption. Fourth, once we have controlled for these three sets of variables, what is in effect a negative Africa dummy coefficient in column 3 of Table 3 disappears. This is in the sense that most African dummy coefficients are positive in Table 6, while most non-African country dummies are negative. All four results follow from the exporting equation estimated for all industries, as well as from the equation estimated for garments and textiles producers only.

We report in column 3 of Table 6, the partial (or marginal) effects of exogenous regressors calculated at their overall sample mean values, along with the McDonaldMoffitt decomposition of each item into effect on a firm's probability of exporting (column 5) and effect on mean exports conditional on exporting (column 4). ${ }^{29}$ It is interesting that, in almost every case, the component due to the effect on the probability of exporting is several times larger than the effect on the average exports of exporters. As can be seen in Tables 7 and 8, the gap between the two components narrows down as we aggregate variables into the two major groups of economic geography and institutions. However, it remains that both geography and institutions influence manufactured exports significantly more through their effect on the number of exporters than through their impact on sales per exporter in foreign markets.

In Tables 7 and 8 we investigate how far individual elements of economic geography and institutional quality account for the observed gap between average firm level exports for the Ugandan sample and those of Morocco and Bangladesh respectively. Uganda is a good illustrative case since its manufacturing industries are significantly less export oriented than those of countries like Kenya and Zimbabwe, but have a significantly higher proportion of exporters compared to most other countries in the region, including 8 of the 10 countries covered by our data (Table 2). ${ }^{30}$ Partly for reasons of economic size, Morocco and Bangladesh also seem to be the more natural comparators to Uganda among the non-African group of 8 .

\footnotetext{
28 This is consistent with results of Wood and Jordan (2000) and of Limao and Venables (2001). The former found Uganda's poor transport infrastructure to be one of the main reasons why its manufactured exports were not as high as Zimbabwe's. It contrasts, though, with the Clarke (2005), who found no evidence that domestic transport infrastructure mattered.

${ }^{29}$ The decomposition is discussed in Wooldridge (2002), the notation of which we have adopted in Tables 7 and 8.

${ }^{30}$ One more good reason for the use of Uganda as an example here is that it was one of the two subjects of the case study of determinants of Africa's manufactured exports by Wood and Jordan (2000), the other being Zimbabwe, also included in our dataset.
} 
As potential exporters Ugandan manufacturers have clear disadvantages over their counterparts in both Morocco and Bangladesh in terms of economic geography. They also seem to operate in a clearly inferior institutional compared to firms in Morocco. To get a sense of the power of the two factors are as influences on the relative export performance of Ugandan industry, we use reduced form parameter estimates of column 1 of Table 6 to estimate what Uganda's average firm level exports would be if Uganda had the economic geography and institutions of Morocco while retaining all the other characteristics of Ugandan firms and their environment as they actually are. The results are reported in column 1 of Table 7. We similarly calculate Uganda's counterfactuals at Bangladeshi economic geography and institutions in column 1 of Table 8. It turns out that if Ugandan firms had the economic geography and institutional setting of their Moroccan counterparts as measured here, their average exports would be more than 8 times what they in fact are today (column 4 of Table 7). ${ }^{31}$ The implied growth in Uganda's exports would cover the current Uganda-Morocco gap at least 7.16 times over (column 7 of Table 7). Some 63 percent of the same growth would occur through increase in the proportion of firms that export while the balance occurs through increase in average exports of exporters. Similarly, average firm level exports in Uganda would be at least 8.5 percent of what they are today if Uganda had the economic geography and institution of Bangladesh (column 4 of Table 8), wiping out the current Uganda-Bangladesh gap in average firm level exports more than 5.37 times over (column 7 of Table 8). Unlike the Uganda-Morocco exporting gap, however, the Uganda-Bangladesh gap is more due to average exports being lower among Ugandan exporters than because the percentage of exporters itself is smaller in Uganda. Some 58 percent of the growth that would occur in Uganda's average firm level exports if its economic geography and institutions somehow changed to Bangladesh's would occur through increase in average shipments per exporter, the balance coming from increase in the proportion of firms that export.

It is always to tempting to ask as to which of the two sets factors is the more important source of the exporting gap of African manufacturers, the region's economic geography or the quality of its institutions? The answer obviously depends on which part of Africa one is thinking about, as well as on the external comparators against which the gap is measured. This is partly because Africa is extremely heterogeneous in both dimensions. Following up on the Ugandan illustration, the exporting gap of its manufacturers vis-à-vis Morocco's has overwhelmingly more to do with Uganda's poorer institutions than with its more adverse economic geography. Ignoring the partial effects of regressors for which estimated coefficients are not statistically significant in column 1 of Table 6 , the combined share of institutional variables in Uganda-Morocco gap in average firm level exports is 1.8 times the combined share of indicators of economic geography. ${ }^{32}$ On the other hand, Uganda's competitiveness gap against Bangladesh is almost entirely due to its adverse economic geography.

\footnotetext{
${ }^{31}$ As an approximation of true partial effects of the change in regressors from Uganda levels to Morocco's, the exact figure of 8.17 at the bottom of column 4 of Table 7 is actually a lower bound since the partial effects are calculated at current Uganda mean values, and yet the effects are monotonically increasing or decreasing, while the assumed changes in regressors are quite large. The same is indeed true of all entries of Tables 7 and 8 .

${ }^{32}$ The regressors the partial effects of which we ignore in this calculation are country area and openness to trade. The relative share of institutional variables will be even greater if included the effects of these two variables instead.
} 
Located literally at the gates of Europe and having an extensive coastline on a busy sea lane, Morocco clearly has enormous trade cost advantages over land locked Uganda thousands of miles to the south east. Uganda's location is also in poorer neighborhood that is even further away from other hubs of world trade. It is indeed difficult to imagine a developing country that has a greater trade cost advantage over Uganda than Morocco. The average distance from ports of the typical Moroccan firm is miniscule compared to that of the average Ugandan firm. Being a middle income country with a relatively large industrial sector, Morocco also has far greater density than low income Uganda, which is reflected in its greater supplier access. One should therefore expect economic geography to be a major source of Uganda's competitiveness gap with Morocco. That is indeed the case. If Uganda somehow had Morocco' proximity to Western Europe and got some access to the sea but remained old itself otherwise, its average firm level manufactured exports would be at least 1.4 times what they are today (column 4 of Table 7). Further, if Uganda's economy was as big as Morocco's and its industries as spatially concentrated, firm level exports would be 2.6 times what they are today. Improve further Uganda's road transport infrastructure to Morocco's, then Uganda's firm level manufactured exports would be nearly 3 times of what they are today. This is a fairly large number. It has also to be remembered that it is a lower bound estimate. However, the same figure is much smaller than the proportion by which Uganda's firm level exports would increase if the quality of its institutions was somehow raised to Morocco's while retaining other aspects of the Ugandan economy including its geography. In that case Uganda's average firm level exports would be at least 5.35 times what they actually are today, which is the sum of the 3.66 times increase that would follow from raising Uganda's rule of law index t to Morocco's and the 1.69 times increase that would follow if the control of corruption of index rose to the Morocco level.

The average manufacturer in Uganda is also at a considerable trade cost disadvantage visà-vis its counterpart in Bangladesh. This is partly because of Uganda's longer distance from major international markets, while Bangladesh must benefit from its neighborhood to India and its proximity to east Asia. An even more important reason is that the average Ugandan firm is several times further away from the nearest port than the typical manufacturing firm. ${ }^{33}$ Also, Bangladesh is not land locked. Even so, trade cost differences are a much smaller source of the Uganda-Bangladesh competitiveness gap than the fact that Bangladeshi firms benefit from the greater domestic supplier access provided by their national economy. A small part of the competitiveness gap is also due to the fact that, overall, institutional quality is marginally better in Bangladesh. It should be noted, though, that this is in spite of the fact that poorer institutions constitute a powerful drag on average firm level exports in Uganda. In fact, Ugandan average firm level exports would be at least 1.7 times what they actually are if Uganda's control of corruption index were at the level of Bangladesh. This is a large figure. However, it happens to be compensated to a large degree by the fact that Uganda scores significantly better on the rule of law index than Bangladesh. If Uganda had the rule of law index of Bangladesh its average firm level exports would be at least 1.2 times smaller than they are today. When we take this into account firm level exports in Uganda would be 50

\footnotetext{
${ }^{33}$ This aspect of Uganda's geography is also emphasized in Wood and Jordan (2000)
} 
percent higher than what they are now if that country had the quality of institutions of Bangladesh in both dimensions of rule of law and control of corruption. This is a very small figure compared to the competitiveness gap attributable to Uganda's more adverse economic geography.

\section{Conclusion}

This paper is a micro-econometric assessment of the role of economic geography and institutions in Africa's marginalization in world trade in manufactures. It is based on the estimation of a structural firm level exporting equation on a cross-country sample of manufacturing establishments drawn from 188 cities. We read from the raw data that average exports per establishments are smaller for African firms than for businesses in other regions. This is in part because African firms have more adverse economic geography than firms in other regions. It is in part because their institutional environment is poorer. The effect of economic geography on exports has two distinct channels. One is lower foreign market access, meaning that the typical African firm is located further away from wealthier or denser potential export markets. The other is lower supplier access, meaning that African firms face steeper input prices, in part because they are further away from otherwise cheaper foreign suppliers, and partly because of the higher prices of domestic substitutes for importable inputs. The effect of institutions on exports is also partly transmitted through lower supplier access and lower foreign market access. But institutions affect exports directly also.

There is no evidence of average exports per firm being lower for Africa once we account for the effects of economic geography and institutions. Given the strong interaction between the effects of economic geography and of institutions on exports, and given the extreme heterogeneity of the region in both respects, it probably is not useful to compare the relative strength of institutions and geography for the region as a whole. The reason is that the outcome would depend on which African country is being compared and against which non-African benchmark. Depending on the choice of subject and comparator, there are scenarios in which economic geography would seem to account for the greater share of observed exporting gaps. There are also cases in which institutions are by far the more important factor. For example, we show that, a far greater share of the export gap of Uganda vis-à-vis Morocco is explained by Uganda's poorer institutions than that which can be accounted for by Morocco's proximity to Western Europe and its greater economic density. On the other hand, the fact that Uganda's average firm level exports are so much lower than Bangladesh's seems to have relatively little to do with institutional gaps.

It is only fitting that we conclude by pointing out the more serious of the limitations in our method and data by way of qualifying our results. The main reservation regarding method is that we would be more confident of the validity of our instruments if we directly tested for over identification and the weak instrument problem directly in a tobit setting. It also remains to be seen whether or not our main conclusions hold up in analysis based on a similar firm level dataset, but one drawn from a larger and more 
diverse set of countries and locations, and including a longer time series of more disaggregated indicators of the quality of institutions.

\section{References}

Amemiya, T. 1978. "The estimation of a simultaneous equation generalized probit model," Econometrica, 46, pp. 1193-1205.

Bigsten, A. P. Collier, S. Dercon, M. Fafchamps, B. Gauthier, J. W. Gunning, J. Habarurema, A. Isaksson, A. Oduro, R. Oostendorp, C. Pattillo, M. Soderbom, F. Teal and A. Zeufack. 1999."Export of African Manufactures: Macro Policy and Firm Behaviour," 1999, Journal of International Trade and Economic Development, 8(1), pp. 53-71.

Bloom, D. and J. Sachs. 1998. "Geography, Demography, and Economic Growth in Africa," in Brooking Papers on Economic Activity, 2.

Clarke, G. 2005. "Beyond Tariffs and Quotas: Why Don't African Manufacturers Export More?" World Bank Policy Research Working Paper \# 3617, June.

Collier, P. .1997. "Globalization: What Should be the African Policy Response? " mimeo, Centre for the Study of African Economies, University of Oxford. , P. .1998. "Globalization: Implications for African Economic Management", Mimeo, World Bank, Washington, D.C.

Cragg, J. and S. Donald. 1993. "Testing Identifiability and Specification in Instrumental Variable Models," Econometric Theory, 9, pp. 222-240.

Dollar, D., M. Hallward-Driemeier, and T. Mengistae. 2005. "Investment Climate and International Integration,” World Bank Policy Research Working Paper \# 3323. June.

Eifert, B. A. Gelb, and V. Ramachandran. 2005. "Business Environment and Comparative Advantage in Africa: Evidence from the Investment Climate Data," Processed, World Bank Group, January.

Elbadawi, I.1994. "Estimating Long-Run Equilibrium Real Exchange Rates", in John Williamson (editor). Estimating Equilibrium Exchange Rates. Institute for International Economics, Washington, DC, USA. 1999: Real Exchange Rate Policy and Non- Traditional Exports in Developing Countries. WIDER Research for Action 46.

Elbadawi, I.A. and C.C. Soludo, 1999. "Our Destiny in Our Hands: Achieving manufactures competitiveness despite the constraints of geography in Africa”. Mimeo. 
Fujita, M., Krugman, P., and Venables, A.J. 1999. The Spatial Economy: Cities, Regions, and International Trade. MIT Press.

Gallup, J. L. and J. D. Sachs. 1998. ' Geography and Economic Growth,' in B. Pleskovic and J. E. Stiglitz (eds.), Proceedings of the World Bank Annual Conference on Development Economics, World Bank.

Gawande, K. 1997. "Generated regressors in linear and nonlinear models," Economics Letters, 54, pp. 119-126.

Kaufmann, D., A. Kraay, and M. Mastruzzi. 2005. "Governance Matters IV: Governance Indicators for 1996-2004,” World Bank Policy Research Working Paper Series \# 3630.

Limao, N. and A. Venables .2001. "Infrastructure, Geographical Disadvantage, Transport costs, and Trade. World Bank Economic Review, 15, pp. 451-479.

Melitz, M. 2003. "The Impact of Trade on Intra-industry Reallocations and Aggregate Industry Productivity,” Econometrica, 71, pp.1695-1725.

Mengistae, T. and Catherine Pattillo. 2004. "Export Orientation and Productivity in SubSaharan Africa,” IMF Staff Papers, 51, pp.327-353.

Moulton, B. 1986. "Random Group Effects and the Precision of Regression Estimates," Journal of Econometrics, 32, pp. 385-397. 1990. "An illustration of a pitfall in estimating the effects of aggregate variables on micro units," Review of Economics and Statistics, 72, pp.334-338.

Nelson, C. and R. Startz. 1990. "Some Further Results on the Exact Small Sample Properties of the Instrumental Variable Estimator," Econometrica, 58, pp.967-976.

Newey, W. 1987. "Efficient Estimation of Limited Dependent Variable Models with Endogenous Explanatory Variables," Journal of Econometrics, 36, pp. 231-250.

Pagan, A. R. 1984. "Econometric issues in the analysis of regressions with generated regressors," International Economic Review, 25, pp. 221-247.

Radelet, S. and J. Sachs .1998. "Shipping costs, Manufacturing Exports, and Economic Growth. Paper Presented at the American Economic Association Meetings, Harvard University.

Redding, S. and A.J. Venables .2000."Economic Geography and International Inequality," Discussion Paper No. 2568, Centre for Economic Policy Research, September. 2004. "Economic geography and international inequality," Journal of International Economics, 62, pp. 53-82. 
Sachs, J., and Warner. 1997. 'Sources of Slow Growth in African Economies,' Journal of African Economies, Vol. 6, pp. 335-76.

Shea, J. 1997. "Instrument Relevance in Multivariate Linear Models: A Simple Measure," Review of Economics and Statistics, 79, pp. 348-352.

Smith, R. and R. Blundell. 1986. "An Exogeneity Test for a Simultanous Equation Tobit Model with an Application to Labor Supply," Econometrica, 54, pp.679-685.

Staiger, D. and J. Stock. 1997. "Instrumental Variable Regression with Weak Instruments," Econometrica, 65, pp.557-586.

Stock, J. and M. Yogo. 2003. "Testing for Weak Instruments in Linear IV Regression," Processed, Department of Economics, Harvard University.

Wood, A. 1997. 'Openness and wage inequality in developing countries: the Latin American challenge to East Asian conventional wisdom,' World Bank Economic Review $11: 33-57$.

Wood, A. and K. Berge. 1997. 'Exporting Manufactures: Human Resources. Natural Resources and Trade Policy,' Journal of Development Studies, Vol. 34, pp. 35-59.

Wood, A. and K. Jordan. 2000. "Why Does Zimbabwe Export Manufactures and Uganda Not? Econometrics Meets History," Journal of Development Studies, 37, pp.91-116.

Wood, A. and J. Mayer. 1998. ' Africa’s Export Structure in Comparative Perspective,' forthcoming in the UNCTAD series Economic Development and Regional Dynamics in Africa: Lessons from the East Asian Experience.

Wooldridge, J. 2002. Econometric Analysis of Cross Section and Panel Data. MIT Press: Cambridge, MA.

World Bank .2000. Can Africa Claim the 21st Century, The World Bank, Washington D.C., June. 
Figure 1: Average Foreign Market Access Relative to India's

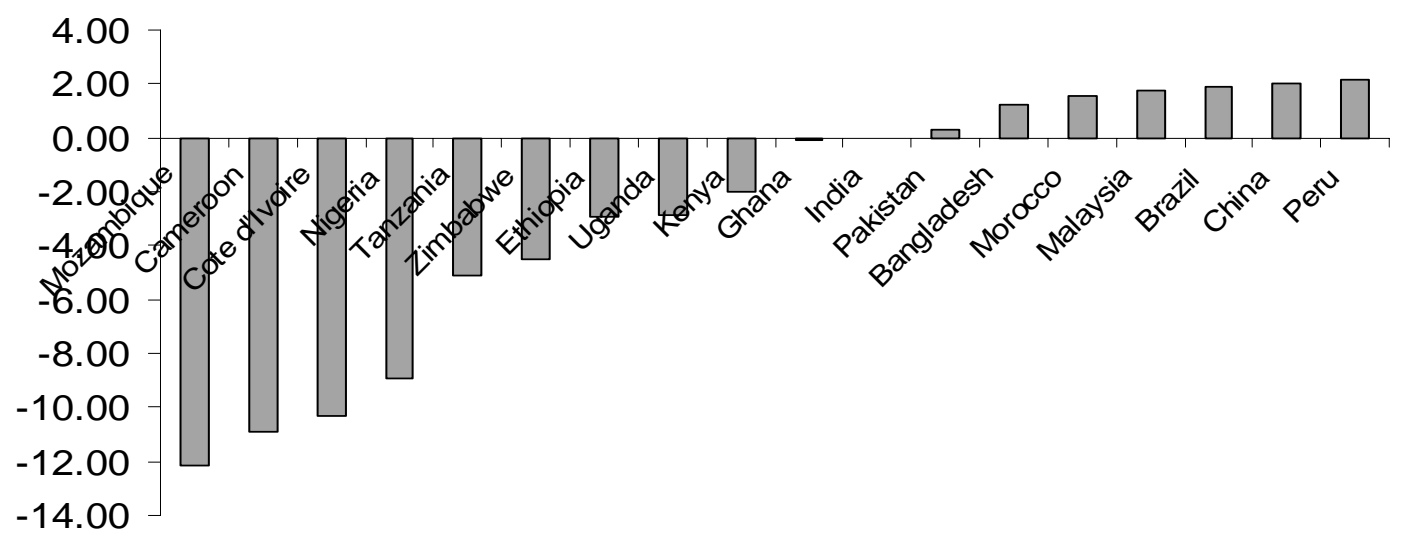

Figure 2: Average National Supplier Access Relative to India's

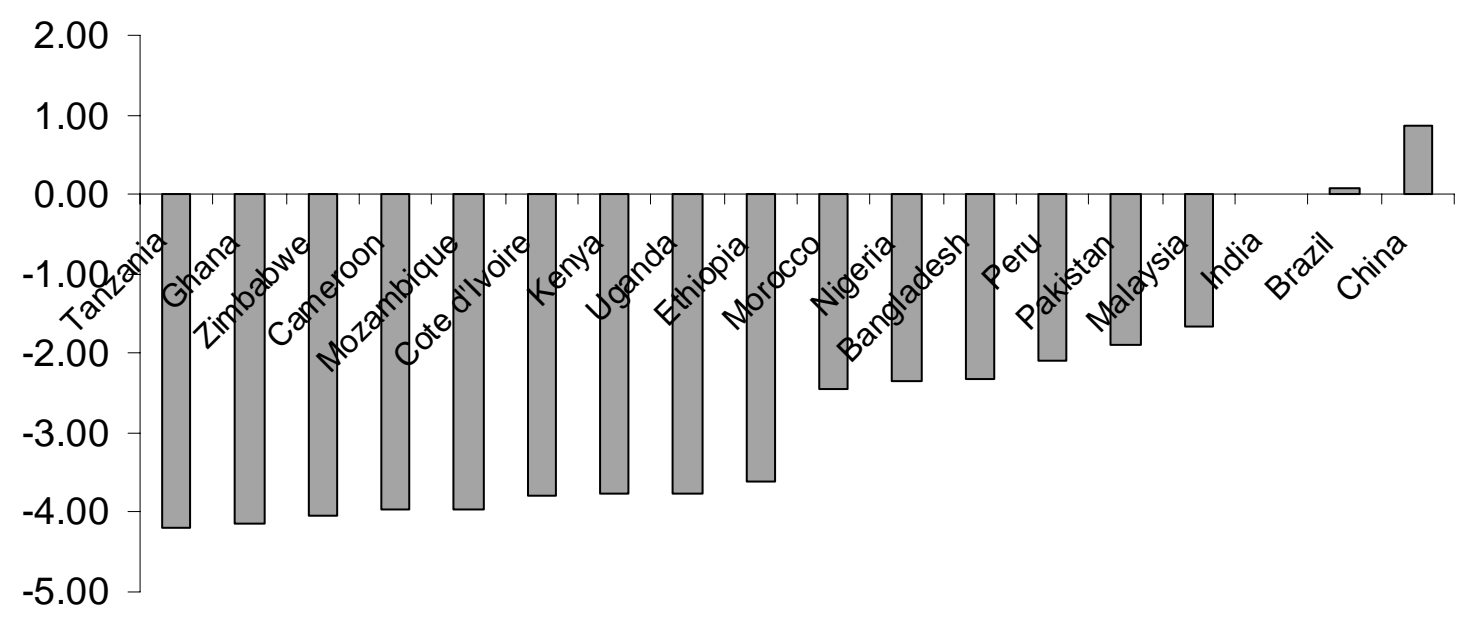

Figure 3: Average Local Supplier Access Relative to India's

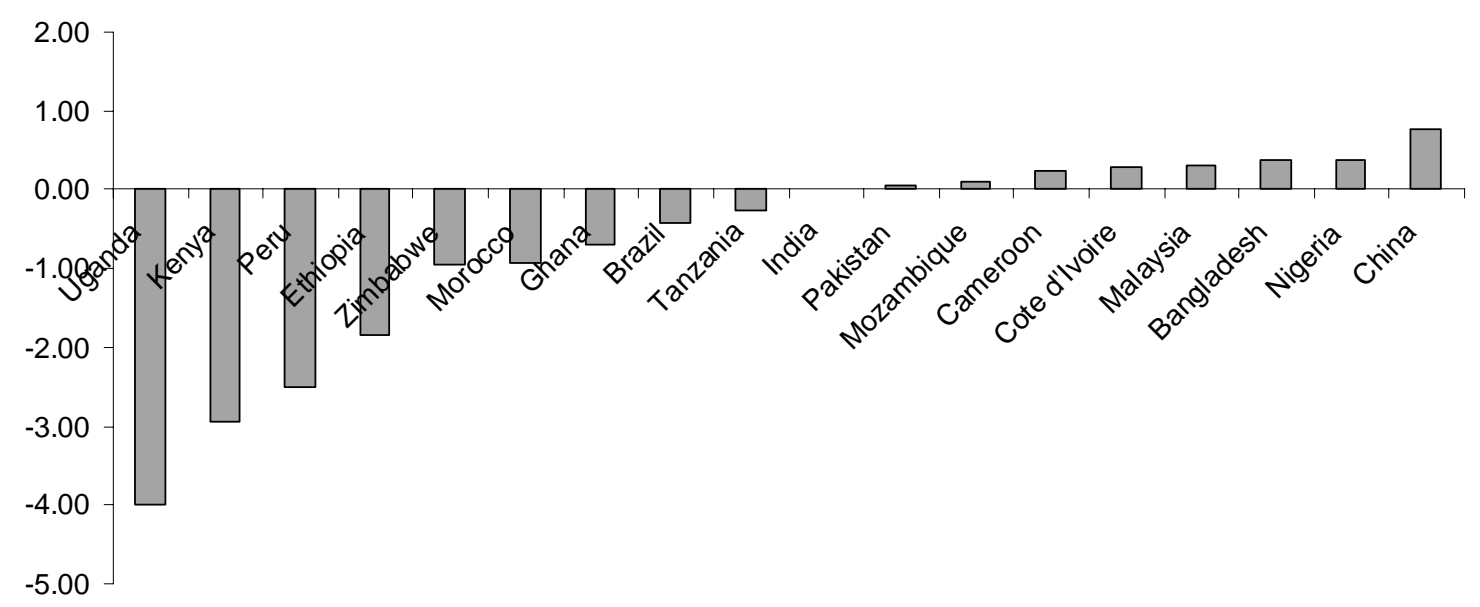


Table 1: List of variables and descriptive statistics

\begin{tabular}{|c|c|c|c|c|c|}
\hline \multirow[t]{3}{*}{ Variable } & \multirow[t]{3}{*}{ Definition } & \multicolumn{4}{|c|}{ Descriptive stat } \\
\hline & & \multicolumn{2}{|c|}{ All Industries } & \multicolumn{2}{|c|}{ Garments/ textiles } \\
\hline & & Mean & SD & Mean & SD \\
\hline \multicolumn{6}{|l|}{ Business characteristics: } \\
\hline Log (exports) & Log of Exports in 1999 US Dollars & 3.93 & 9.39 & 2.28 & 10.51 \\
\hline Log (employment) & Log of number of employees at the end of the fiscal year & 3.76 & 1.80 & 3.97 & 1.84 \\
\hline Log (age) & Lgo of number of years since the establishment started operations & 2.37 & 0.91 & 2.36 & 0.86 \\
\hline Foreign owned & Dummy $=1$ if the establishment has foreign share holders & 0.13 & 0.34 & 0.08 & 0.28 \\
\hline \multicolumn{6}{|l|}{ Market and supplier access variables: } \\
\hline National supplier access & See text for definition & 26.99 & 1.72 & & \\
\hline Local supplier access & See text for definition & 27.81 & 1.26 & & \\
\hline Foreign market access & See text for definition & 32.39 & 3.88 & & \\
\hline \multicolumn{6}{|l|}{ Geographic (trade cost) variables: } \\
\hline International distance & Log km distance to port * national CIF to FOB ratio for 1995 & 2.42 & 5.36 & & \\
\hline Area & Log of country area in square kms. & 14.10 & 1.40 & & \\
\hline Land locked & Dummy $=1$ if country is land locked & 0.11 & & & \\
\hline \multicolumn{6}{|l|}{ Lagged economic density variables: } \\
\hline Country population (lagged) & Log of country population lagged 5 years & 4.91 & 1.65 & & \\
\hline Local GDP (1995) & Log (Country PPP GDP in $1990^{*}$ Population share of city in 1995) & 21.25 & 2.41 & & \\
\hline Percent paved (road network) & Percentage of total road network that was paved by 1990 & 30.63 & 20.23 & & \\
\hline \multicolumn{6}{|l|}{ Institution and policy indicators: } \\
\hline Openness to trade & Sachs-Warner index of openness $1965-1990$ & 0.04 & 0.12 & & \\
\hline Rule of law & Kaufmann et al rule of law index 1996-2002 & -0.28 & 0.48 & & \\
\hline Control of corruption & Kaufman et al control of corruption index, 1996-2002 & -0.41 & 0.41 & & \\
\hline \multicolumn{6}{|l|}{ Sectors of industry: } \\
\hline Food & & 0.10 & & & \\
\hline Textiles & & 0.13 & & & \\
\hline Garment & & 0.15 & & & \\
\hline Leather products & & 0.04 & & & \\
\hline Furniture & & 0.11 & & & \\
\hline Electronics and electrical equipment & & 0.11 & & & \\
\hline Pharmaceuticals and chemicals & & 0.11 & & & \\
\hline Autos and parts & & 0.05 & & & \\
\hline Machinery & & 0.03 & & & \\
\hline other & & 0.18 & & & \\
\hline
\end{tabular}

Table 2: Sample Average Firm Level Exports by Country

\begin{tabular}{l|r|rr|r}
\hline & \multicolumn{1}{|c|}{$\begin{array}{c}\text { Number of } \\
\text { establishments }\end{array}$} & $\begin{array}{l}\text { Average firm level annual exports } \\
\text { (log of 1999 US dollars) }\end{array}$ & $\begin{array}{c}\text { Proportion } \\
\text { that } \\
\text { export }\end{array}$ \\
\cline { 3 - 4 } & & All firms & Exporters \\
only & & 18.54 & 0.40 \\
\hline Bangladesh & 1,001 & 7.43 & 17.72 & 0.10 \\
Brazil & 1,642 & 1.74 & 18.83 & 0.25 \\
China & 1,661 & 4.73 & 17.49 & 0.10 \\
Cameroon & 199 & 1.76 & 16.73 & 0.12 \\
Cote d'Ivoire & 230 & 2.23 & 16.80 & 0.06 \\
Ethiopia & 422 & 0.94 & 16.55 & 0.12 \\
Ghana & 318 & 1.94 & 17.59 & 0.21 \\
India & 3,015 & 3.66 & 17.19 & 0.22 \\
Kenya & 517 & 3.70 & 18.53 & 0.57 \\
Malaysia & 893 & 10.51 & 18.18 & 0.34 \\
Morocco & 859 & 6.17 & 16.26 & 0.08 \\
Mozambique & 153 & 1.35 & 16.30 & 0.03 \\
Nigeria & 232 & 0.42 & 17.95 & 0.19 \\
Pakistan & 965 & 3.49 & 10.49 & 0.03 \\
Peru & 576 & 0.35 & 16.83 & 0.13 \\
Tanzania & 428 & 2.16 & 16.45 & 0.18 \\
Uganda & 786 & 2.88 & 16.78 & 0.44 \\
Zimbabwe & 200 & 7.38 & 17.95 & 0.22 \\
\hline Total & 14098 & 3.93 & &
\end{tabular}


Table 3: Regression of firm level exports on country dummies and access variables, all industries Dependent variable : Log (exports)

\begin{tabular}{|c|c|c|c|c|}
\hline & \multicolumn{2}{|c|}{ OLS } & \multicolumn{2}{|c|}{$\begin{array}{l}\text { Tobit by maximum } \\
\text { likelihood }\end{array}$} \\
\hline & $(1)$ & $(2)$ & (3) & (4) \\
\hline National supplier access & $\begin{array}{l}2.268 \\
(13.99)^{\star *}\end{array}$ & & & $\begin{array}{l}19.135 \\
(18.99)^{\star \star}\end{array}$ \\
\hline Local supplier access & $\begin{array}{l}1.111 \\
(16.40)^{\star \star}\end{array}$ & & & $\begin{array}{l}6.171 \\
(15.27)^{\star \star}\end{array}$ \\
\hline Foreign market access & $\begin{array}{l}-0.050 \\
(2.32)^{\star}\end{array}$ & & & $\begin{array}{l}0.265 \\
(3.01)^{\star *}\end{array}$ \\
\hline Log (employment) & $\begin{array}{l}1.671 \\
(66.06)^{\star \star}\end{array}$ & & & $\begin{array}{l}8.466 \\
(53.41)^{\star \star}\end{array}$ \\
\hline Log (age) & $\begin{array}{l}0.092 \\
(1.96)\end{array}$ & & & $\begin{array}{l}0.065 \\
(0.37)\end{array}$ \\
\hline Foreign owned & $\begin{array}{l}4.032 \\
(27.08)^{\star \star}\end{array}$ & & & $\begin{array}{l}11.100 \\
(25.68)^{\star \star}\end{array}$ \\
\hline Control of corruption & $\begin{array}{l}3.470 \\
(9.48)^{* *}\end{array}$ & & & $\begin{array}{l}18.651 \\
(14.84)^{\star \star}\end{array}$ \\
\hline Bangladesh & $\begin{array}{l}3.025 \\
(12.15)^{\star \star}\end{array}$ & $\begin{array}{l}5.519 \\
(29.12)^{\star \star}\end{array}$ & $\begin{array}{l}20.122 \\
(26.48)^{\star \star}\end{array}$ & $\begin{array}{l}8.090 \\
(9.73)^{\star *}\end{array}$ \\
\hline Malaysia & $\begin{array}{l}1.577 \\
(3.29)^{\star \star}\end{array}$ & $\begin{array}{l}9.358 \\
(47.30)^{\star \star}\end{array}$ & $\begin{array}{l}29.937 \\
(40.26)^{\star \star}\end{array}$ & $\begin{array}{l}-13.564 \\
(8.59)^{\star \star}\end{array}$ \\
\hline China & $\begin{array}{l}-9.068 \\
(17.64)^{\star \star}\end{array}$ & $\begin{array}{l}1.917 \\
(12.11)^{\star \star}\end{array}$ & $\begin{array}{l}7.913 \\
(9.30)^{\star \star}\end{array}$ & $\begin{array}{l}-70.896 \\
(20.76)^{\star \star}\end{array}$ \\
\hline India & $\begin{array}{l}-5.491 \\
(10.87)^{\star \star}\end{array}$ & $\begin{array}{l}0.719 \\
(5.40)^{\star \star}\end{array}$ & $\begin{array}{l}3.671 \\
(4.91)^{\star \star}\end{array}$ & $\begin{array}{l}-46.832 \\
(17.92)^{\star \star}\end{array}$ \\
\hline Brazil & $\begin{array}{l}-9.595 \\
(17.77)^{\star \star}\end{array}$ & $\begin{array}{l}-1.353 \\
(8.07)^{\star \star}\end{array}$ & $\begin{array}{l}-8.752 \\
(8.53)^{\star \star}\end{array}$ & $\begin{array}{l}-65.918 \\
(23.66)^{\star \star}\end{array}$ \\
\hline Cameroon & $\begin{array}{l}2.861 \\
(5.00)^{\star *}\end{array}$ & $\begin{array}{l}0.181 \\
(0.41)\end{array}$ & $\begin{array}{l}1.592 \\
(0.62)\end{array}$ & $\begin{array}{l}36.707 \\
(11.51)^{\star \star}\end{array}$ \\
\hline Cote D'ivoire & $\begin{array}{l}-1.533 \\
(3.81)^{\star \star}\end{array}$ & $\begin{array}{l}0.733 \\
(1.76)\end{array}$ & $\begin{array}{l}4.878 \\
(1.87)\end{array}$ & $\begin{array}{l}9.655 \\
(3.81)^{\star *}\end{array}$ \\
\hline Ghana & $\begin{array}{l}2.910 \\
(6.64)^{\star \star}\end{array}$ & $\begin{array}{l}-0.432 \\
(1.31)\end{array}$ & $\begin{array}{l}-2.376 \\
(1.43)\end{array}$ & $\begin{array}{l}30.585 \\
(12.57)^{\star \star}\end{array}$ \\
\hline Mozambique & $\begin{array}{l}-3.450 \\
(9.73)^{\star \star}\end{array}$ & $\begin{array}{l}-1.740 \\
(4.01)^{\star \star}\end{array}$ & $\begin{array}{l}-11.922 \\
(5.00)^{\star \star}\end{array}$ & $\begin{array}{l}4.915 \\
(1.75)\end{array}$ \\
\hline Nigeria & $\begin{array}{l}-6.540 \\
(21.73)^{\star \star}\end{array}$ & $\begin{array}{l}-3.430 \\
(9.74)^{\star \star}\end{array}$ & $\begin{array}{l}-30.642 \\
(8.25)^{\star \star}\end{array}$ & $\begin{array}{l}-34.619 \\
(11.35)^{\star *}\end{array}$ \\
\hline Kenya & $\begin{array}{l}8.170 \\
(14.74)^{\star \star}\end{array}$ & $\begin{array}{l}1.829 \\
(6.86)^{\star \star}\end{array}$ & $\begin{array}{l}10.256 \\
(8.23)^{\star \star}\end{array}$ & $\begin{array}{l}56.032 \\
(19.44)^{\star \star}\end{array}$ \\
\hline Tanzania & $\begin{array}{l}4.075 \\
(9.32)^{\star \star}\end{array}$ & $\begin{array}{l}-0.261 \\
(0.93)\end{array}$ & $\begin{array}{c}-1.592 \\
(1.06)\end{array}$ & $\begin{array}{l}37.430 \\
(14.57)^{\star \star}\end{array}$ \\
\hline Uganda & $\begin{array}{l}6.856 \\
(15.21)^{\star \star}\end{array}$ & $\begin{array}{l}0.189 \\
(0.90)\end{array}$ & $\begin{array}{l}2.014 \\
(2.22)^{\star}\end{array}$ & $\begin{array}{l}52.284 \\
(20.14)^{\star \star}\end{array}$ \\
\hline Zimbabwe & $\begin{array}{l}6.996 \\
(13.51)^{\star \star}\end{array}$ & $\begin{array}{l}7.362 \\
(16.85)^{\star \star}\end{array}$ & $\begin{array}{l}32.620 \\
(19.71)^{\star \star}\end{array}$ & $\begin{array}{l}44.846 \\
(18.84)^{\star \star}\end{array}$ \\
\hline Industry sector dummies & Yes & Yes & Yes & Yes \\
\hline Year dummies & Yes & Yes & Yes & Yes \\
\hline Constant & $\begin{array}{l}-94.267 \\
(18.56)^{\star \star}\end{array}$ & $\begin{array}{l}-2.565 \\
(10.77)^{\star \star}\end{array}$ & $\begin{array}{l}-42.272 \\
(44.08)^{\star \star}\end{array}$ & $\begin{array}{l}-735.014 \\
(23.04)^{\star \star}\end{array}$ \\
\hline Estimated sigma [standard error] & & & $29.90[0.12]$ & $25.32[0.15]$ \\
\hline Observations & 39002 & 39002 & 39002 & 39002 \\
\hline R-squared & 0.222 & 0.09 & & \\
\hline Pseudo R-squared & & & 0.03 & 0.09 \\
\hline Log likelihood & & & -57992 & -54541 \\
\hline
\end{tabular}


Table 4: Insturmental variable estimation of exports equations

\begin{tabular}{|c|c|c|c|c|c|c|c|}
\hline \multirow{3}{*}{ Dependent variable $=\log$ exports } & \multicolumn{4}{|c|}{ All industries in the sample } & \multicolumn{3}{|c|}{ Garments and textiles only } \\
\hline & \multirow{2}{*}{\begin{tabular}{|l|}
$2 S L S$ \\
$(1)$ \\
\end{tabular}} & \multicolumn{3}{|c|}{$\begin{array}{l}\text { Newy's Minimum Chi-square } \\
\text { Tobit Estimator }\end{array}$} & \multirow{2}{*}{\begin{tabular}{|l|}
$2 S L S$ \\
$(5)$ \\
\end{tabular}} & \multicolumn{2}{|c|}{$\begin{array}{l}\text { Newy's Minimum Chi-square } \\
\text { Tobit Estimator }\end{array}$} \\
\hline & & (2) & $(3)$ & $(4)$ & & (6) & $(7)$ \\
\hline National supplier access & $\begin{array}{l}2.846 \\
(5.27)^{\star *}\end{array}$ & $\begin{array}{l}12.924 \\
(3.67)^{\star *}\end{array}$ & $\begin{array}{l}7.569 \\
(1.77)\end{array}$ & $\begin{array}{l}17.168 \\
(13.63)^{\star *}\end{array}$ & $\begin{array}{l}1.387 \\
(3.68)^{* *}\end{array}$ & $\begin{array}{l}5.922 \\
(2.56)^{*}\end{array}$ & $\begin{array}{l}10.127 \\
(2.96)^{* *}\end{array}$ \\
\hline Local supplier access & $\begin{array}{l}2.799 \\
(9.77)^{\star \star}\end{array}$ & $\begin{array}{l}16.325 \\
(7.23)^{\star *}\end{array}$ & $\begin{array}{l}16.054 \\
(5.91)^{\star *}\end{array}$ & $\begin{array}{l}15.056 \\
(30.44)^{\star \star}\end{array}$ & $\begin{array}{l}4.848 \\
(1.97)^{*}\end{array}$ & $\begin{array}{l}13.976 \\
(0.75)\end{array}$ & $\begin{array}{l}9.537 \\
(1.02)\end{array}$ \\
\hline Foreign market access & $\begin{array}{l}0.365 \\
(1.77)\end{array}$ & $\begin{array}{l}4.251 \\
(2.51)^{*}\end{array}$ & $\begin{array}{l}6.842 \\
(3.31)^{\star *}\end{array}$ & $\begin{array}{l}2.503 \\
(11.61)^{\star \star}\end{array}$ & $\begin{array}{l}0.699 \\
(2.89)^{\star *}\end{array}$ & $\begin{array}{l}3.614 \\
(2.36)^{\star}\end{array}$ & $\begin{array}{l}2.472 \\
(3.56)^{\star *}\end{array}$ \\
\hline Log (employment) & $\begin{array}{l}0.333 \\
(0.61)\end{array}$ & $\begin{array}{l}6.973 \\
(1.86)\end{array}$ & $\begin{array}{l}15.863 \\
(4.35)^{* *}\end{array}$ & & $\begin{array}{l}2.359 \\
(2.20)^{*}\end{array}$ & $\begin{array}{l}8.514 \\
(1.00)\end{array}$ & \\
\hline Log (age) & $\begin{array}{l}-5.928 \\
(1.89)\end{array}$ & $\begin{array}{l}-68.060 \\
(2.59)^{\star *}\end{array}$ & $\begin{array}{l}-101.214 \\
(2.89)^{\star \star}\end{array}$ & & $\begin{array}{l}-2.507 \\
(0.84)\end{array}$ & $\begin{array}{l}-19.206 \\
(0.75)\end{array}$ & \\
\hline Foreign owned & $\begin{array}{l}27.395 \\
(8.40)^{\star \star}\end{array}$ & $\begin{array}{l}98.497 \\
(5.12)^{\star *}\end{array}$ & & & $\begin{array}{l}33.885 \\
(4.59)^{\star \star}\end{array}$ & $\begin{array}{l}98.369 \\
(1.76)\end{array}$ & \\
\hline Control of corruption & $\begin{array}{l}2.610 \\
(3.35)^{\star *}\end{array}$ & $\begin{array}{l}9.796 \\
(1.98)^{*}\end{array}$ & $\begin{array}{l}16.646 \\
(3.14)^{\star *}\end{array}$ & $\begin{array}{l}29.948 \\
(21.39)^{\star *}\end{array}$ & $\begin{array}{l}1.729 \\
(1.67)\end{array}$ & $\begin{array}{l}0.196 \\
(0.04)\end{array}$ & $\begin{array}{l}12.981 \\
(1.66)\end{array}$ \\
\hline Bangladesh & $\begin{array}{l}3.092 \\
(2.18)^{*}\end{array}$ & $\begin{array}{l}-11.622 \\
(1.19)\end{array}$ & $\begin{array}{l}-35.563 \\
(3.28)^{\star *}\end{array}$ & $\begin{array}{l}15.394 \\
(15.51)^{\star \star}\end{array}$ & $\begin{array}{l}0.531 \\
(0.14)\end{array}$ & $\begin{array}{l}-8.722 \\
(0.29)\end{array}$ & $\begin{array}{l}28.011 \\
(9.42)^{\star *}\end{array}$ \\
\hline Malaysia & $\begin{array}{l}-4.591 \\
(4.93)^{\star *}\end{array}$ & $\begin{array}{l}-33.345 \\
(4.66)^{\star *}\end{array}$ & $\begin{array}{l}-19.278 \\
(2.96)^{\star *}\end{array}$ & $\begin{array}{l}-22.052 \\
(11.67)^{\star *}\end{array}$ & $\begin{array}{l}-3.356 \\
(1.09)\end{array}$ & $\begin{array}{l}-6.299 \\
(0.26)\end{array}$ & $\begin{array}{l}3.865 \\
(0.30)\end{array}$ \\
\hline China & $\begin{array}{l}-17.072 \\
(12.91)^{\star *}\end{array}$ & $\mid \begin{array}{l}-104.648 \\
(9.50)^{* *}\end{array}$ & $\begin{array}{l}-99.287 \\
(6.71)^{\star *}\end{array}$ & $\begin{array}{l}-59.150 \\
(15.55)^{\star \star}\end{array}$ & $\begin{array}{l}-4.537 \\
(0.94)\end{array}$ & $\begin{array}{l}-14.597 \\
(0.36)\end{array}$ & $\begin{array}{l}-50.315 \\
(4.95)^{\star *}\end{array}$ \\
\hline India & $\begin{array}{l}-6.043 \\
(3.65)^{\star *}\end{array}$ & $\begin{array}{l}-23.254 \\
(2.19)^{*}\end{array}$ & $\begin{array}{l}-10.970 \\
(0.83)\end{array}$ & $\begin{array}{l}-49.723 \\
(14.96)^{* *}\end{array}$ & $\mid \begin{array}{l}6.674 \\
(7.71)^{* *}\end{array}$ & $\begin{array}{l}-28.434 \\
(5.64)^{\star *}\end{array}$ & $\begin{array}{l}-17.117 \\
(0.74)\end{array}$ \\
\hline Brazil & $\begin{array}{l}-9.479 \\
(7.23)^{\star *}\end{array}$ & $\begin{array}{l}-44.971 \\
(5.63)^{\star *}\end{array}$ & $\begin{array}{l}-43.510 \\
(4.16)^{\star *}\end{array}$ & $\begin{array}{l}-66.494 \\
(20.35)^{* *}\end{array}$ & & & \\
\hline Cameroon & $\begin{array}{l}2.062 \\
(0.55)\end{array}$ & $\begin{array}{l}62.046 \\
(2.12)^{\star}\end{array}$ & $\begin{array}{l}130.268 \\
(3.59)^{\star \star}\end{array}$ & $\begin{array}{l}54.506 \\
(19.21)^{\star \star}\end{array}$ & $\begin{array}{l}-3.875 \\
(1.07)\end{array}$ & $\begin{array}{l}6.623 \\
(0.11)\end{array}$ & $\begin{array}{l}12.481 \\
(0.43)\end{array}$ \\
\hline Cote D'ivoire & $\begin{array}{l}-0.564 \\
(0.50)\end{array}$ & $\begin{array}{l}16.359 \\
(2.21)^{\star}\end{array}$ & $\begin{array}{l}27.394 \\
(2.81)^{\star \star}\end{array}$ & $\begin{array}{l}10.345 \\
(4.10)^{\star \star}\end{array}$ & $\mid \begin{array}{l}1.324 \\
(0.24)\end{array}$ & $\begin{array}{l}8.457 \\
(0.28)\end{array}$ & $\begin{array}{l}40.722 \\
(1.73)\end{array}$ \\
\hline Ghana & $\begin{array}{l}0.219 \\
(0.16)\end{array}$ & $\begin{array}{l}-0.789 \\
(0.09)\end{array}$ & $\begin{array}{l}-3.560 \\
(0.32)\end{array}$ & $\begin{array}{l}28.613 \\
(9.31)^{\star *}\end{array}$ & $\begin{array}{l}-1.425 \\
(0.69)\end{array}$ & $\begin{array}{l}-17.821 \\
(0.21)\end{array}$ & $\begin{array}{l}107.983 \\
(2.00)^{\star}\end{array}$ \\
\hline Mozambique & $\begin{array}{l}-8.696 \\
(2.87)^{\star *}\end{array}$ & $\begin{array}{l}-3.431 \\
(0.17)\end{array}$ & $\begin{array}{l}58.691 \\
(2.23)^{*}\end{array}$ & $\begin{array}{l}15.746 \\
(5.39)^{\star *}\end{array}$ & $\begin{array}{l}-20.031 \\
(3.49)^{\star *}\end{array}$ & $\begin{array}{l}-56.429 \\
(0.50)\end{array}$ & $\begin{array}{l}-55.798 \\
(1.22)\end{array}$ \\
\hline Nigeria & $\begin{array}{l}-8.954 \\
(2.57)^{\star}\end{array}$ & \begin{tabular}{|l}
-18.445 \\
$(0.68)$
\end{tabular} & $\begin{array}{l}44.770 \\
(1.44)\end{array}$ & $\begin{array}{l}1.144 \\
(0.40)\end{array}$ & $\begin{array}{l}-26.579 \\
(5.43)^{\star \star}\end{array}$ & $\begin{array}{l}-68.759 \\
(2.33)^{*}\end{array}$ & $\begin{array}{l}48.285 \\
(6.51)^{\star \star}\end{array}$ \\
\hline Kenya & $\begin{array}{l}14.537 \\
(5.62)^{\star *}\end{array}$ & $\begin{array}{l}101.042 \\
(4.85)^{\star *}\end{array}$ & $\begin{array}{l}124.624 \\
(4.40)^{\star *}\end{array}$ & $\begin{array}{l}88.335 \\
(28.42)^{* \star}\end{array}$ & $\begin{array}{l}13.619 \\
(1.53)\end{array}$ & $\begin{array}{l}47.617 \\
(0.72)\end{array}$ & $\begin{array}{l}-42.151 \\
(1.43)\end{array}$ \\
\hline Tanzania & $\begin{array}{l}4.435 \\
(3.28)^{\star \star}\end{array}$ & $\begin{array}{l}31.865 \\
(3.61)^{\star *}\end{array}$ & $\begin{array}{l}45.261 \\
(3.72)^{\star *}\end{array}$ & $\begin{array}{l}47.939 \\
(19.84)^{\star \star}\end{array}$ & $\begin{array}{l}7.198 \\
(1.85)\end{array}$ & $\begin{array}{l}4.770 \\
(0.07)\end{array}$ & $\begin{array}{l}47.838 \\
(0.66)\end{array}$ \\
\hline Uganda & $\begin{array}{l}8.644 \\
(5.02)^{\star *}\end{array}$ & $\begin{array}{l}57.365 \\
(5.33)^{\star *}\end{array}$ & $\begin{array}{l}72.225 \\
(5.14)^{\star *}\end{array}$ & $\begin{array}{l}92.044 \\
(27.60)^{* *}\end{array}$ & $\begin{array}{l}12.300 \\
(1.26)\end{array}$ & $\begin{array}{l}75.407 \\
(1.11)\end{array}$ & $\begin{array}{l}-8.778 \\
(0.23)\end{array}$ \\
\hline Zimbabwe & $\begin{array}{l}11.659 \\
(4.64)^{\star *}\end{array}$ & $\begin{array}{l}82.862 \\
(4.06)^{\star *}\end{array}$ & $\begin{array}{l}105.118 \\
(3.66)^{\star *}\end{array}$ & $\begin{array}{l}59.960 \\
(27.06)^{* *}\end{array}$ & $\begin{array}{l}3.643 \\
(1.01)\end{array}$ & $\begin{array}{l}1.040 \\
(0.03)\end{array}$ & $\begin{array}{l}-15.542 \\
(0.57)\end{array}$ \\
\hline Industry sector dummies & Yes & Yes & Yes & Yes & & & \\
\hline Year dummies & Yes & Yes & Yes & Yes & Yes & Yes & Yes \\
\hline Constant & $\begin{array}{l}-152.851 \\
(8.93)^{\star \star}\end{array}$ & $\begin{array}{l}-830.187 \\
(7.71)^{\star \star}\end{array}$ & $\begin{array}{l}-711.731 \\
(5.01)^{\star \star} \\
\end{array}$ & $\begin{array}{l}-966.176 \\
(25.29)^{\star \star} \\
\end{array}$ & $\begin{array}{l}-126.293 \\
(1.74)\end{array}$ & \begin{tabular}{|l}
-531.482 \\
$(0.90)$
\end{tabular} & $\begin{array}{l}-15.504 \\
(0.06) \\
\end{array}$ \\
\hline $\begin{array}{l}\text { Observations } \\
\text { Hausman-Wu test statistic (F) }\end{array}$ & $\begin{array}{l}39002 \\
81.4\end{array}$ & 39002 & 39002 & 39002 & $\begin{array}{l}11608 \\
17.1\end{array}$ & 11608 & 11608 \\
\hline $\begin{array}{l}\text { Smith-Blundell exogeneity test statistic }(F) \\
\text { Sargan's test } p \text {-value } \\
\text { Cragg-Donald weak instrument test statist }\end{array}$ & $\begin{array}{l}0.89 \\
20.67\end{array}$ & 85.3 & 87.51 & 135.4 & \begin{tabular}{|l}
0.29 \\
18.33
\end{tabular} & 8.62 & 6.14 \\
\hline
\end{tabular}


Table 5: Summary of First stage regression results of 2SLS Estimation of Expors Equation

\begin{tabular}{|c|c|c|c|c|}
\hline \multirow[b]{2}{*}{ Endogenous regressor } & \multicolumn{2}{|c|}{ All Industry } & \multicolumn{2}{|c|}{ Garments and Textiles } \\
\hline & $\begin{array}{l}\text { Shea Partial } \\
\text { R-squared }\end{array}$ & $\begin{array}{c}\text { Partial } \\
\text { R-squared }\end{array}$ & $\begin{array}{c}\text { Shea Partial } \\
\text { R-squared }\end{array}$ & $\begin{array}{c}\text { Partial } \\
\text { R-squared }\end{array}$ \\
\hline National supplier access & 0.36 & 0.97 & 0.28 & 0.97 \\
\hline Local supplier access & 0.25 & 0.71 & 0.15 & 0.54 \\
\hline Foreing market access & 0.09 & 0.45 & 0.11 & 0.39 \\
\hline Log (employment) & 0.03 & 0.19 & 0.01 & 0.01 \\
\hline $\log ($ age $)$ & 0.01 & 0.06 & 0 & 0.01 \\
\hline Foreing owned & 0.04 & 0.08 & 0.01 & 0.04 \\
\hline
\end{tabular}


Table 6: Maximum Likelihood Estimates of the Reduced Form Tobit and Partial Effects at Mean Values of Exogenous Regressors.

\begin{tabular}{|c|c|c|c|c|c|}
\hline \multirow{2}{*}{$\begin{array}{l}\text { Regessors=x } \\
\text { (industry and time dummies included) }\end{array}$} & \multirow[t]{2}{*}{ All Industries ${ }^{* * * *}$} & \multirow[t]{2}{*}{ Garment/textiles ${ }^{* * *}$} & \multicolumn{3}{|c|}{ Partial Effects (all industry) on } \\
\hline & & & $E(y \mid x)$ & $E(y \mid x, y>0)^{\star \star \star}$ & $\mathrm{P}(\mathrm{y}>0)^{* * *}$ \\
\hline \multirow[t]{2}{*}{ International distance } & -0.412 & -0.287 & -0.087 & -0.005 & -0.082 \\
\hline & $(10.53)^{\star *}$ & $(4.85)^{\star *}$ & $(11.79)^{\star *}$ & & \\
\hline \multirow[t]{2}{*}{ Land locked } & -12.691 & -18.854 & -0.022 & -0.106 & 0.084 \\
\hline & $(3.85)^{* *}$ & $(1.71)$ & $(3.65)^{\star *}$ & & \\
\hline \multirow[t]{2}{*}{ Area } & -7.262 & -26.158 & -1.784 & -0.100 & -1.684 \\
\hline & $(0.83)$ & $(9.89)^{\star *}$ & $(1.07)$ & & \\
\hline \multirow[t]{2}{*}{ Country population (lagged) } & 23.661 & 32.453 & 4.717 & 0.266 & 4.451 \\
\hline & $(3.57)^{\star \star}$ & $(3.00)^{\star *}$ & $(3.77)^{\star *}$ & & \\
\hline \multirow[t]{2}{*}{ Local GDP (1995) } & 0.286 & 0.754 & 0.060 & 0.003 & 0.057 \\
\hline & $(2.18)^{*}$ & $(2.70)^{\star *}$ & $(2.45)^{*}$ & & \\
\hline \multirow[t]{2}{*}{ Percent paved (road network) } & 0.109 & 0.419 & 0.020 & 0.001 & 0.019 \\
\hline & $(2.35)^{*}$ & $(5.77)^{\star \star}$ & $(2.30)^{*}$ & & \\
\hline \multirow[t]{2}{*}{ Openness to trade } & 39.978 & 73.586 & 11.280 & 0.635 & 10.645 \\
\hline & $(0.64)$ & $(0.85)$ & $(0.97)$ & & \\
\hline \multirow[t]{2}{*}{ Rule of law } & 21.445 & 12.795 & 4.087 & 0.230 & 3.857 \\
\hline & $(9.03)^{\star \star}$ & $(1.88)$ & $(9.13)^{\star *}$ & & \\
\hline \multirow[t]{2}{*}{ Control of corruption } & 13.298 & 18.417 & 2.521 & 0.142 & 2.379 \\
\hline & $(6.89)^{\star \star}$ & $(5.65)^{\star *}$ & $(6.93)^{\star *}$ & & \\
\hline \multirow[t]{2}{*}{ Bangladesh } & 21.186 & -53.532 & 9.554 & 0.330 & 9.224 \\
\hline & $(1.26)$ & $(7.75)^{\star \star}$ & $(1.44)$ & & \\
\hline \multirow[t]{2}{*}{ Malaysia } & 18.189 & 26.680 & 10.129 & 0.349 & 9.78 \\
\hline & $(1.01)$ & $(1.18)$ & $(1.41)$ & & \\
\hline \multirow[t]{2}{*}{ China } & -82.252 & -7.541 & -5.253 & -0.318 & -4.935 \\
\hline & $(2.31)^{*}$ & $(0.33)$ & $(2.50)^{*}$ & & \\
\hline \multirow[t]{2}{*}{ India } & -82.935 & -37.769 & -8.496 & -0.445 & -8.051 \\
\hline & $(3.21)^{\star \star}$ & $(1.81)$ & $(3.43)^{\star \star}$ & & \\
\hline \multirow[t]{2}{*}{ Brazil } & -56.811 & & -4.213 & -0.273 & -3.94 \\
\hline & $(2.55)^{\star}$ & & $(2.81)^{\star \star}$ & & \\
\hline \multirow[t]{2}{*}{ Cameroon } & 64.746 & 56.590 & 48.612 & 0.801 & 47.811 \\
\hline & $(3.26)^{\star \star}$ & $(2.26)^{\star}$ & $(3.72)^{\star *}$ & & \\
\hline \multirow[t]{2}{*}{ Cote D'ivoire } & 41.131 & 12.459 & 24.561 & 0.651 & 23.91 \\
\hline & $(1.83)$ & $(0.43)$ & $(2.11)^{*}$ & & \\
\hline Ghana & 22.270 & -15.087 & 10.381 & 0.353 & 10.028 \\
\hline & $(2.39)^{\star}$ & (1.93) & $(2.71)^{\star \star}$ & & \\
\hline Mozambique & -1.765 & -15.526 & -0.138 & -0.109 & -0.029 \\
\hline & $(0.04)$ & $(0.22)$ & $(0.27)$ & & \\
\hline Nigeria & -26.832 & -34.525 & -1.112 & -0.148 & -0.964 \\
\hline & $(8.65)^{\star \star}$ & $(4.09)^{\star \star}$ & $(6.97)^{\star \star}$ & & \\
\hline Kenya & 43.411 & 31.044 & 22.889 & 0.636 & 22.253 \\
\hline & $(6.77)^{\star \star}$ & $(2.77)^{\star *}$ & $(7.16)^{\star *}$ & & \\
\hline Tanzania & 19.885 & 46.375 & 9.570 & 0.327 & 9.243 \\
\hline & $(2.42)^{\star}$ & $(2.77)^{\star *}$ & $(2.87)^{\star *}$ & & \\
\hline Uganda & 54.940 & 3.731 & 34.726 & 0.766 & 33.96 \\
\hline & $(3.60)^{\star \star}$ & $(0.32)$ & $(4.01)^{\star \star}$ & & \\
\hline Zimbabwe & 67.671 & 80.067 & 48.562 & 0.801 & 47.761 \\
\hline & $(3.48)^{\star \star}$ & $(4.42)^{\star \star}$ & $(3.80)^{\star \star}$ & & \\
\hline Constant & -254.151 & 168.035 & & & \\
\hline & $(1.70)$ & $(2.88)^{\star \star}$ & & & \\
\hline sigma [standard error] & $25.18[0.22]$ & $21.71[0.30]$ & & & \\
\hline Observations & 39002 & 11608 & & & \\
\hline Log likelihood & -54418 & -19279 & & & \\
\hline
\end{tabular}


Table 7. Changes in Uganda's average firm level exports tif some of it Indicators changed to Morocco's

\begin{tabular}{|c|c|c|c|c|c|c|c|c|c|}
\hline \multirow[b]{3}{*}{ Selected regressors } & \multicolumn{9}{|c|}{ Effect of change in regressors, $x$, from Uganda levels to Morocco levels, on Uganda's firm level exports, $y$} \\
\hline & \multicolumn{3}{|c|}{$\begin{array}{l}\text { A. Calculated at average of Uganda's } \\
\text { and Morocco's means }\end{array}$} & \multicolumn{3}{|c|}{$\begin{array}{l}\text { B. Entries of panel A as proportions of } \\
\text { Uganda's average firm level exports } \\
\text { (all firms) }\end{array}$} & \multicolumn{3}{|c|}{$\begin{array}{l}\text { C. Entries of panel A as a proportion of } \\
\text { the excess of Morocco's average } \\
\text { average exports over Uganda's }\end{array}$} \\
\hline & $\begin{array}{l}\text { Partial effect } \\
\text { on } E(y \mid x)\end{array}$ & $\begin{array}{l}\text { Effect through } \\
\text { change in } \\
P(y>0)\end{array}$ & $\begin{array}{l}\text { Effect through } \\
\text { change in } \\
E(y \mid x, y>0)\end{array}$ & $\begin{array}{l}\text { Partial effect } \\
\text { on } E(y \mid x)\end{array}$ & $\begin{array}{l}\text { Effect through } \\
\text { change in } \\
P(y>0)\end{array}$ & $\begin{array}{l}\text { Effect throug } \\
\text { change in } \\
E(y \mid x, y>0)\end{array}$ & $\begin{array}{l}\text { Partial effect } \\
\text { on } E(y \mid x)\end{array}$ & $\begin{array}{l}\text { Effect through } \\
\text { change in } \\
P(y>0)\end{array}$ & $\begin{array}{l}\text { Effect through } \\
\text { change in } \\
E(y \mid x, y>0)\end{array}$ \\
\hline \multicolumn{10}{|l|}{ 1. Trade cost related variables : } \\
\hline 1.1. International distance & 2.47 & 1.06 & 1.42 & 0.86 & 0.37 & 0.49 & 0.75 & 0.32 & 0.43 \\
\hline 1.2. Area & -3.74 & 1.56 & -5.29 & -1.30 & 0.54 & -1.84 & -1.14 & 0.47 & -1.61 \\
\hline 1.3. Land locked & 1.52 & 2.49 & 0.97 & 0.53 & 0.86 & -0.34 & 0.46 & 0.76 & -0.29 \\
\hline 1.4. Total & 0.26 & 5.10 & -2.91 & 0.09 & 1.77 & -1.68 & 0.08 & 1.55 & -1.47 \\
\hline \multicolumn{10}{|l|}{ 2. Economic density indicators: } \\
\hline 2.1. Country population (lagged) & 3.15 & 1.31 & 1.84 & 1.09 & 0.46 & 0.64 & 0.96 & 0.40 & 0.56 \\
\hline 2.2 Local GDP (1995) & 0.50 & 0.22 & 0.28 & 0.17 & 0.08 & 0.10 & 0.15 & 0.07 & 0.08 \\
\hline 2.3. Percent paved (road network) & 0.86 & 0.43 & 0.43 & 0.30 & 0.15 & 0.15 & 0.26 & 0.13 & 0.13 \\
\hline 2.4. Total & 4.51 & 1.96 & 2.55 & 1.57 & 0.68 & 0.88 & 1.37 & 0.60 & 0.77 \\
\hline \multicolumn{10}{|l|}{ 3. Institutions/policy indicators: } \\
\hline 3.1. Openness to trade & 3.39 & 0.98 & -0.03 & 1.18 & 0.49 & 0.69 & 1.03 & 0.43 & 0.60 \\
\hline 3.2. Rule of law & 10.54 & 3.05 & -0.10 & 3.66 & 1.52 & 2.14 & 3.20 & 1.33 & 1.87 \\
\hline 3.3. Control of corruption & 4.86 & 1.40 & -0.04 & 1.69 & 0.70 & 0.99 & 1.48 & 0.61 & 0.86 \\
\hline 3.4. Total & 18.78 & 5.43 & 13.35 & 6.52 & 2.71 & 3.81 & 5.71 & 2.37 & 3.34 \\
\hline \multicolumn{10}{|l|}{ Grand total } \\
\hline$(=1.4+2.4+3.4)$ & 23.55 & 12.49 & 11.06 & 8.17 & 5.16 & 3.01 & 7.16 & 4.52 & 2.64 \\
\hline
\end{tabular}

Table 8. Changes in Uganda's average firm level exports tif some of it Indicators changed to Bangladesh levels

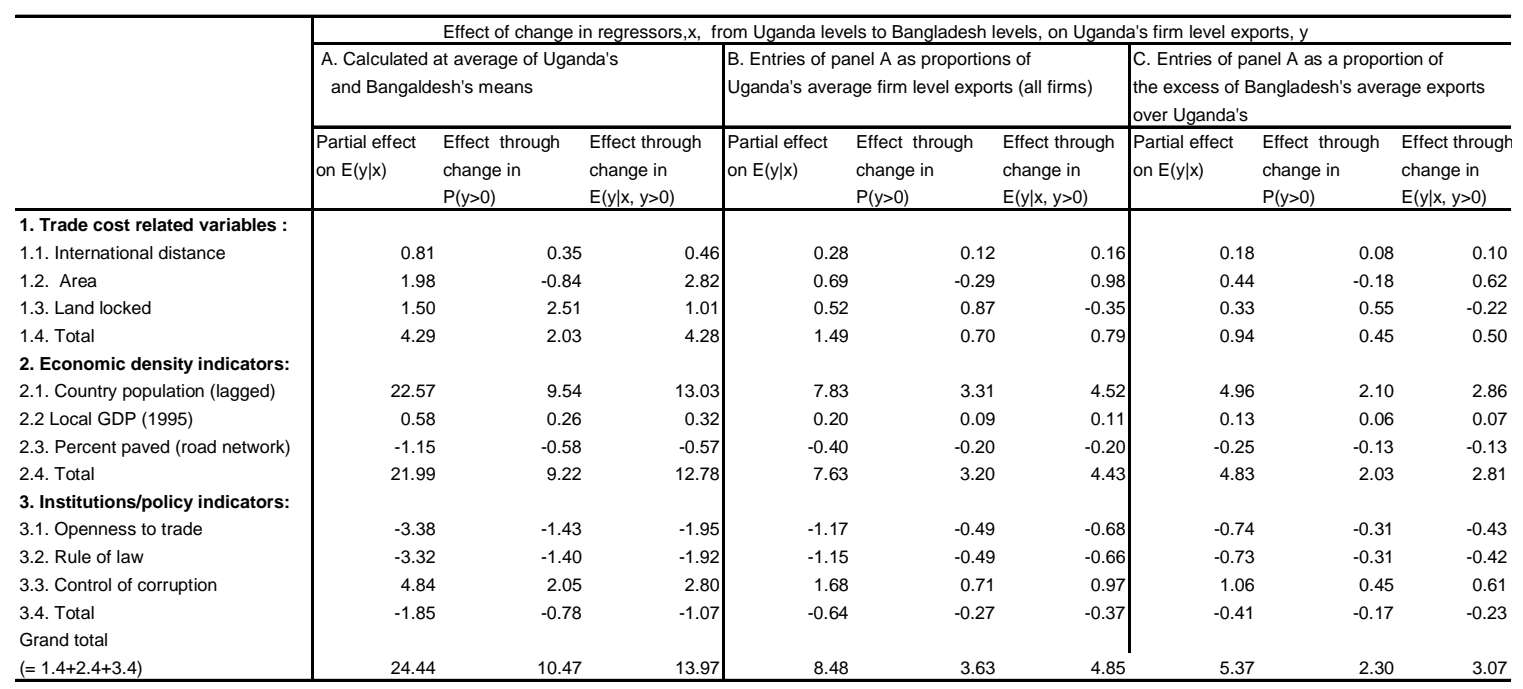

